\section{UCDNN}

LIBRARY
University of Connecticut OpenCommons@UConn

Center for Health, Intervention, and Prevention

$1-1-1990$

\title{
Gender and Leadership Style: A Meta-Analysis
}

Alice H. Eagly

Purdue University, eagly@northwestern.edu

Blair T. Johnson

University of Connecticut, blair.t.johnson@uconn.edu

Follow this and additional works at: https://opencommons.uconn.edu/chip_docs

Part of the Social Psychology Commons

\section{Recommended Citation}

Eagly, Alice H. and Johnson, Blair T., "Gender and Leadership Style: A Meta-Analysis" (1990). CHIP Documents. 11. https://opencommons.uconn.edu/chip_docs/11 


\title{
Gender and Leadership Style: A Meta-Analysis
}

\author{
Alice H. Eagly and Blair T. Johnson \\ Purdue University
}

\begin{abstract}
Research comparing the leadership styles of women and men is reviewed, and evidence is found for both the presence and the absence of differences between the sexes. In contrast to the gender-stereotypic expectation that women lead in an interpersonally oriented style and men in a task-oriented style, female and male leaders did not differ in these two styles in organizational studies. However, these aspects of leadership style were somewhat gender stereotypic in the two other classes of leadership studies investigated, namely (a) laboratory experiments and (b) assessment studies, which were defined as research that assessed the leadership styles of people not selected for occupancy of leadership roles. Consistent with stereotypic expectations about a different aspect of leadership style, the tendency to lead democratically or autocratically, women tended to adopt a more democratic or participative style and a less autocratic or directive style than did men. This sex difference appeared in all three classes of leadership studies, including those conducted in organizations. These and other findings are interpreted in terms of a social role theory of sex differences in social behavior.
\end{abstract}

In recent years many social scientists, management consultants, and other writers have addressed the topic of gender and leadership style. Some authors with extensive experience in organizations who write nontechnical books for management audiences and the general public have argued for the presence of sex differences in leadership style. For example, Loden (1985) maintained that there is a masculine mode of management characterized by qualities such as competitiveness, hierarchical authority, high control for the leader, and unemotional and analytic problem solving. Loden argued that women prefer and tend to behave in terms of an alternative feminine leadership model characterized by cooperativeness, collaboration of managers and subordinates, lower control for the leader, and problem solving based on intuition and empathy as well as rationality. Loden's writing echoes the androgynous manager theme developed earlier by Sargent (1981), who accepted the idea that women and men, including those who are managers in organizations, behave stereotypically to some extent. Sargent advocated that managers of each sex adopt "the best" of the other

This research was supported by National Science Foundation Grants BNS-8605256 and BNS-8807495. Preliminary reports of this research were presented at the Annual Meetings of the Eastern Psychological Association, April 1988; the Midwestern Psychological Association, April 1988; the International Congress of Psychology, September 1988; and the American Psychological Association, August 1989. A table showing the effect sizes and study characteristics for each study included in the meta-analysis is available from the first author.

We thank Anna Fairchild for assistance in locating studies and in recording and checking data. We also thank Judith Hall, Edwin P. Hollander, Judi Komaki, Louis Sternberg, Howard Weiss, and Wendy Wood for comments on a draft of the article and Katherine Markee for help in conducting computer-based information searches.

Blair T. Johnson is now at Syracuse University.

Correspondence concerning this article should be addressed to Alice H. Eagly, Department of Psychological Sciences, Purdue University, West Lafayette, Indiana 47907. sex's qualities to become more effective, androgynous managers. In a somewhat different rendition of this sex-difference theme, Hennig and Jardin (1977) also acknowledged sex-differentiated managerial behavior, which they ascribed to personality traits acquired in early socialization, particularly through differing male and female resolutions of the Oedipus complex.

In contrast to these generalizations about gender-stereotypic leadership styles promulgated in books written primarily for practicing managers and the general public, social scientists have generally maintained that there are in fact no reliable differences in the ways that women and men lead. Although a few social scientists have acknowledged that there is some evidence for sex differences in leadership style among research participants who have not been selected for occupancy of leadership roles in natural settings (e.g., Brown, 1979; Hollander, 1985), most have agreed that women and men who occupy leadership roles in organizations do not differ (but see Shakeshaft, 1987, for a contrasting opinion). Illustrating this consensus among social scientists are the following representative statements summarizing research comparing the styles of female and male leaders: "The preponderance of available evidence is that no consistently clear pattern of differences can be discerned in the supervisory style of female as compared to male leaders" (Bass, 1981 , p. 499); "Contrary to notions about sex specialization in leadership styles, women leaders appear to behave in similar fashion to their male colleagues" (Nieva \& Gutek, 1981, p. 91); "There is as yet no research evidence that makes a case for sex differences in either leadership aptitude or style" (Kanter, 1977 a, p. 199); "In general, comparative research indicates that there are few differences in the leadership styles of female and male designated leaders" (Bartol \& Martin, 1986, p. 278).

Underlying this divergence in the opinions voiced in popular and social scientific writings is the fact that authors in these two camps have based their conclusions on quite different kinds of data. Authors such as Loden (1985) who have written books for managers and the general public based their conclusions pri- 
marily on their own experience in organizations as well as on the impressions they gleaned from interviews with practicing managers. Social scientists typically based their conclusions on more formal studies of managerial behavior in which data were gathered via questionnaires or behavioral observations and then analyzed quantitatively. In view of these contrasting methods, it is tempting for social scientists to dismiss the generalizations that are based on personal experience and interviews, and to accept as valid only those conclusions that stem from more formal empirical research on leadership. However, the generalizations that social scientists appear to have accepted in this area, which stem from reviews of empirical research (c.g., Bartol \& Martin, 1986), arc quite vulnerable to error because of the relatively informal methods by which reviewers have drawn conclusions from the available research. With only one exception, ${ }^{1}$ these reviews were traditional, narrative reviews and, therefore, were not based on any clear rules about how one derives conclusions from research findings. Moreover, none of the existing reviews was based on more than a small proportion of the available studies. For example, both Bartol and Martin (1986) and Dobbins and Platz (1986) based their generalizations on eight studies that compared the leadership styles of men and women, yet we located 162 studies pertaining only to the four types of leadership style we included in our meta-analysis (see Method). Moreover, prior reviewers did not state the criteria by which they selected their small samples of studies. As we became aware of these selection problems and of the severe underuse of available research on gender and leadership style, we decided that a thorough survey of this domain was long overdue. Our meta-analysis thus provides a systematic, quantitative integration of the available research in which the leadership styles of men and women were compared and statistical analyses were performed on the resulting data.

\section{Theoretical Analysis of Sex Differences in Leadership Style}

Leaving aside the claims of both the social scientists and the management experts who have written about gender and leadership style, we face a topic of considerable complexity that we analyze from several perspectives. One of our perspectives takes into account existing knowledge about sex differences in social behaviors such as aggression, helping, and conformity as well as numerous nonverbal and communicative behaviors. Large numbers of laboratory and field studies have been performed on such behaviors, primarily by social psychologists, and in many of these studies female and male behavior has been compared. Quantitative reviews of this research have established the presence rather than the absence of overall sex differences (see overviews by Eagly, 1987; Eagly \& Wood, in press; Hall, 1984). These differences, although typically not large, tend to be comparable in magnitude to most other findings reported in social psychological research. On the average, sex appears to be a variable that has neither especially impactful nor especially weak effects on social behavior and that produces findings consistent with laypeople's ideas about how the sexes differ (see Eagly, 1987).

Reasons to expect the absence of sex differences in leadership style. Despite the gender-stereotypic findings generally pro- duced in studies of social behavior, similar results would not necessarily be obtained for leaders and managers because of important differences between leadership research and typical research in social psychology. In particular, the majority of leadership studies have been performed in organizations. In contrast, most social psychological research has been carried out in experimental laboratories and to a lesser extent in field settings not embedded within organizations (e.g., on street corners). In such environments, subjects interact with strangers on a short-term basis, and the constraints of organizational and familial roles are generally minimal or absent. Consequently, there is often considerable ambiguity about how one should behave, and people may react in terms of quite global and readily observable attributes of themselves and others (e.g., sex, age, race, and general physical appearance). In situations of this type, gender roles, which are rules about how one should behave as a male or female, may provide more guidance than they otherwise would and thus produce gender-stereotypic behavior.

Behavior may be less stereotypic when women and men who occupy the same managerial role are compared because these organizational leadership roles, which typically are paid jobs, usually provide fairly clear guidelines about the conduct of behavior. Managers become socialized into their roles in the early stages of their experience in an organization (see Feldman, 1976; Graen, 1976; Terborg, 1977; Wanous, 1977). In addition, male and female managers have presumably been selected by organizations (and have selected themselves into these roles) according to the same set of organizationally relevant criteria, further decreasing the likelihood that the men and women who occupy these roles differ substantially in their style. Thus, reasonable assumptions about socialization into leadership roles and selection for these roles suggest that male and female leaders who occupy the same organizational role should differ very little. Managers of both sexes are presumably more concerned about managing effectively than about representing sexdifferentiated features of societal gender roles.

This argument that organizational roles should override gender roles is consistent with Kanter's (1977a) structural interpretation of organizational behavior. Kanter argued that apparent sex differences in the bchavior of organizational leaders are in fact a product of the differing structural positions of the sexes within organizations. Because women are more often in positions of little power or opportunity for advancement, they behave in ways that reflect their lack of power. Kanter's reasoning thus suggests that women and men who are equivalent in terms of status and power would behave similarly, even though sex differences may appear to be substantial when women and

\footnotetext{
${ }^{1}$ The one available quantitative review of sex differences in leadership style (Dobbins \& Platz, 1986) unfortunately included studies with designs not suited for examining these differences. These inappropriate studies investigated bias in subjects' perceptions of leaders by equalizing the behavior of male and female leaders and varying only the leader's sex (Butterfield \& Powell, 1981; Lee \& Alvares, 1977). Because equivalence of malc and female behavior was ensured in these studies, they cannot be regarded as assessing sex differences in leadership style.
} 
men are compared without control of their organizational status.

Reasons to expect the presence of sex differences in leadership style. Despite these reasons for arguing that differences between female and male organizational leaders should be minimal, other perspectives suggest that sex differences may be common, especially in some types of leadership research. As our reasoning has already implied, the social structural rationale for the absence of differences between occupants of the same managerial role within organizations is fully consistent with the presence of differences in leadership studies that compare women and men in other circumstances. In the leadership literature, there are two major types of studies that did not examine organizational leaders-namely, laboratory experiments, usually conducted with college students, and assessment studies, which we defined as research assessing the styles of people who were not selected for occupancy of leadership positions. Because the social structural rationale for the absence of differences between women and men in the same organizational role is not relevant to studies of these two types, sex-differentiated leadership styles are likely to be prevalent in such research, just as gender-stereotypic behavior is commonly found in social psychological research more generally.

There are, in addition, several reasons to suggest that male and female organizational leaders, even those who occupy the same positions, may differ to some extent in their leadership style despite the structural forces for minimizing differences that we have already noted. One such reason acknowledges the possibility of ingrained sex differences in personality traits and behavioral tendencies, differences that are not nullified by organizational selection or socialization. For example, some psychologists have maintained that sex differences in adult social behavior are in part a product of biological influences such as the greater prenatal androgynization of males (e.g., Money \& Ehrhardt, 1972). Other psychologists have emphasized the importance of childhood events that are different for the sexes such as experiences that occur in sex-segregated play groups in which girls and boys play in different styles and use different methods of influencing one another (Maccoby, 1988). Thus, it is possible that biological sex differences and sex-differentiated prior experiences cause men and women to be somewhat different kinds of people, even if they do occupy the same managerial role. It may not be possible to find men and women who are so nearly equivalent that trait-level differences disappear entirely, even though sex differences in the behavior of organizational leaders may be smaller than those in the general population. In particular, men and women may come to managerial roles with a somewhat different set of skills. Especially relevant is the evidence meta-analyses have provided for women's social skills: Women as a group, when compared with men as a group, can be described as friendly, pleasant, interested in other people, expressive, and socially sensitive (see Eagly, 1987; Hall, 1984). To the extent that such findings reflect ingrained sex differences that are not leveled by organizational selection or socialization, male and female managers may behave differently, despite structural forces toward sameness.

Another perspective suggesting that leader behavior may be somewhat sex differentiated in organizations postulates gender-role spillover, which is "a carryover into the workplace of gender-based expectations for behavior" (Gutek \& Morasch, 1982, p. 58; see also Nieva \& Gutek, 1981). The spillover concept suggests that gender roles may contaminate organizational roles to some extent and cause people to have different expectations for female and male managers. In support of this idea, Russell, Rush, and Herd (1988) found that university women described an effective female (vs. male) leader as exhibiting higher levels of both the interpersonally oriented and the taskoriented aspects of leadership (i.e., higher in consideration and initiation of structure; see discussion of these variables in next subsection). ${ }^{2}$

Consistent with the idea that gender roles spill over to organizational roles, several social scientists have claimed that female leaders and managers experience conflict between their gender role and their leadership role (see Bass, 1981; Bayes \& Newton, 1978; Kruse \& Wintermantel, 1986; O'Leary, 1974). This conflict arises for female leaders because the stereotype of manager and the normative expectations associated with being a good manager include more masculine than feminine qualities (see Powell, 1988). The idea that women are subjected to incompatible expectations from the managerial and the female role thus presumes that gender roles are important within organizations.

Another manifestation of the spillover of gender roles onto organizational roles is that people who hold positions in organizations tend to have negative attitudes about women occupying managerial roles. Reflecting the subordinate status of women in the society, numerous studies have shown that people are often reluctant to have a female supervisor and think that women are somewhat less qualified for leadership and that female managers would have negative effects on morale (see reviews by O'Leary, 1974; Riger \& Galligan, 1980; Terborg, 1977). Because these attitudes and beliefs raise questions about women's competence, ability to lead, and potential for advancement, female managers often face a less supportive environment than male managers. Sex differences in leadership style might result from this aspect of gender-role spillover as well as from the other aspects we have noted.

Finally, some of the fine-grained features of the structural interpretation of organizational behavior suggest other possible sources of sex differences in the behavior of organizational leaders. One such consideration is that, as Kanter (1977b) pointed out, women in managerial roles often have the status of token because of their rarity in such positions. Thus, female managers commonly are members of a numerically small minority, whereas their male counterparts are members of a majority group. As Kanter and others argued, token status increases one's visibility (Taylor, Fiske, Etcoff, \& Ruderman, 1978) and can have a number of negative implications for how one is perceived and treated, especially when the token is a woman (Crocker \& McGraw, 1984; Ott, 1989; Yoder \& Sinnett, 1985). In

\footnotetext{
${ }^{2}$ Whercas the belief that effective female managers are especially concerned about relationships may reflect stereotypic beliefs about women in general, the belief that effective female managers are especially concerned about task accomplishment may reflect a more complex theory about women having to perform extremely well to succeed as managers.
} 
addition, even those female and male leaders who occupy the same organizational role may differ systematically in seniority, salary, the availability of mentoring and informal collegial support, and other characteristics that convey some of the subtleties of organizational status. Women, especially as relative newcomers in many managerial roles, tend to have less status in these ways, and this difference may be reflected in their behavior.

In summary, ingrained sex differences in traits and behavioral tendencies, a spillover of gender roles onto organizational roles, and subtle differences in the structural position of women and men could cause leadership behavior to be somewhat sex-differentiated even when occupants of the same organizational role are compared. Therefore, some evidence of sex differences in leadership style in organizational studies would not be surprising. Nonetheless, our reasoning that organizational roles are more important than gender roles led us to predict that differences between men and women occupying the same leadership role in organizations would be smaller than differences between men and women observed in other types of leadership research, namely laboratory experiments and assessment studies.

\section{Design of the Meta-Analysis}

Types of leadership style. The fact that investigators have examined many facets of leadership style (see Bass, 1981) requires that reviewers decide which facets to include and how to organize them into types. In examining this issue, we found that the majority of the studies had assessed the extent to which leaders or managers were concerned with two aspects of their work. The first of these aspects we termed task accomplishment, (or, for brevity, task style)-that is, organizing activities to perform assigned tasks. The second aspect we termed maintenance of interpersonal relationships (or, for brevity, interpersonal style) - that is, tending to the morale and welfare of the people in the setting.

This distinction between task and interpersonal styles was first represented in leadership research by Bales (1950), who proposed two categories of leaders, those with an orientation to task accomplishment and those with a socioemotional orientation indicative of concern for morale and relationships among group members. This distinction was developed further in the Ohio State studies on leadership (e.g., Halpin, 1957; Halpin \& Winer, 1957; Hemphill \& Coons, 1957; Stogdill, 1963). In this research, task orientation, labeled initiation of structure, included behavior such as having subordinates follow rules and procedures, maintaining high standards for performance, and making leader and subordinate roles explicit. Interpersonal orientation, labeled consideration, included behavior such as helping and doing favors for subordinates, looking out for their welfare, explaining procedures, and being friendly and available. Task and interpersonal orientations are typically regarded as separate, relatively orthogonal dimensions (e.g., in the Leader Behavior Description Questionnaire [LBDQ] constructed by the Ohio State researchers; Halpin \& Winer, 1957). Less commonly, these orientations are treated as two ends of a single continuum (e.g., in the Least Preferred Co-Worker [LPC] instrument; Fiedler, 1967). ${ }^{3}$
Task and interpersonal styles in leadership research are obviously relevant to gender because of the stereotypes people have about sex differences in these aspects of behavior (see Ashmore, Del Boca, \& Wohlers, 1986; Eagly \& Steffen, 1984). Men are believed to be more self-assertive and motivated to master their environment (e.g., more aggressive, independent, self-sufficient, forceful, dominant). In contrast, women are believed to be more selfless and concerned with others (e.g, more kind, helpful, understanding, warm, sympathetic, aware of others' feelings). In research on gender, these two orientations have been labeled masculine and feminine, instrumental and expressive, and agentic and communal. Although the task and interpersonal dimensions studied in leadership research are not as broad as these very general tendencies examined in gender stereotype research, the ideas are quite similar. Therefore, leadership research provides an excellent opportunity to determine whether the behavior of leaders is gender stereotypic.

The only other aspect of leadership style studied frequently enough to allow us to represent it in our meta-analysis is the extent to which leaders (a) behave democratically and allow subordinates to participate in decision making, or (b) behave autocratically and discourage subordinates from participating in decision-making. The dimension of democratic versus autocratic leadership (or participative vs. directive leadership) follows from early experimental studies of leadership style (e.g., Lewin \& Lippitt, 1938) and has been developed since that time by a number of researchers (e.g., Likert, 1961; Vroom \& Yetton, 1973). Although democratic versus autocratic style is a different (and narrower) aspect of leader bchavior than task-oriented and interpersonally oriented styles (see Bass, 1981), the democraticautocratic dimension also relates to gender stereotypes, because one component of the agentic or instrumental aspect of these stereotypes is that men are relatively dominant and controlling (i.e., more autocratic and directive than women).

Methods of assessing leadership style. The diversity of the methods that have been used to assess style complicates the task of integrating research in this area. Moreover, a substantial methodological literature criticizes and compares these measures (see Bass, 1981). Because the methodological issues that have been raised remain largely unresolved by leadership researchers, we did not attempt to settle these issues in order to base our meta-analytic generalizations on only those measures that we or other investigators might regard as most valid. Instead, we included all measures that researchers regarded as assessing task-oriented and interpersonally oriented styles or

\footnotetext{
${ }^{3}$ Although the Least Preferred Co-Worker Scale has been given a variety of interpretations, the view that low-L.PC people are task oriented and high-LPC people are relationship oriented seems to be the most widely accepted of these interpretations (see Rice, 1978).

${ }^{4}$ Although Bass (1981) distinguished between (a) democratic versus autocratic leadership and (b) participative versus directive leadership, we treated these measures as a single class because we found this distinction difficult to maintain when categorizing measures. We refer to this single class as democratic versus autocratic style. Researchers have treated this style as a single, bipolar dimension because democratic and autocratic styles presumably are incompatible. In contrast, interpersonal and task styles apparently are not incompatible, as suggested by the preference of most researchers for treating these styles as scparate, relatively orthogonal dimensions.
} 
autocratic versus democratic style. We coded our studies on a number of these measures' features, many of which may be regarded as having implications for the quality of the measures. For example, measures differed in how directly or indirectly they assessed leadership style; the most direct measures were based on observers' coding of ongoing leadership behavior, and the most indirect measures were based on leaders' responses to questionnaire measures of attitudes or personality. Representing such features in our coding scheme (see Method) allowed us to determine whether they covaried with sex differences in leadership style.

Congeniality of leadership roles for men and women. When we thought about gender in relation to the available studies of leadership style, we were struck by the variation in the extent to which the leadership roles investigated in this research (e.g., elementary school principal, nursing supervisor, military officer) would be perceived as congenial mainly for women or men. For leadership roles that are typically regarded as especially suitable for women, negative attitudes toward female leaders presumably would not be prevalent, nor would conflict between the female and the leader role be an issue. Presumably women would be under less pressure to adopt male-stereotypic styles of leadership in such positions.

To enable us to take account of the gender congeniality of leadership roles, we conducted a questionnaire study to obtain judgments of each role, and analyzed these judgments to estimate the extent to which women or men were more interested in each role and believed themselves more competent to perform it. In addition, because people associate task-oriented qualities with men and interpersonally oriented qualities with women, we also determined the extent to which each role was judged to require each set of these gender-stereotypic qualities. These features of our meta-analysis allowed us to determine whether the ascription of gender-stereotypic qualities to leadership roles related to sex differences in the styles by which people carry out these roles.

Predictions for meta-analysis. As we have already stated, our major prediction is that gender-stereotypic sex differences in leadership style are less pronounced in organizational studies comparing occupants of the same managerial role than in leadership studies of other types. Beyond this prediction, our purposes as reviewers are primarily descriptive and exploratory, even though other predictions might follow from the issues we have discussed. For example, if, as we suggested, female managers often face a less supportive environment than do male managers, these women might strive so hard to overcome antifemale prejudices that they behave counterstereotypically as a result. Additional complexities enter if we reason that ratings of leaders' behavior could produce findings that are more stereotypic than those produced by measures grounded more firmly in behavior. Rather than set forth a series of speculative hypotheses that take these and other considerations into account, we prefer to present our review and to discuss such issues as they become relevant to interpreting our meta-analytic findings.

\section{Method}

\section{Sample of Studies}

Computer-based information searches were conducted using the keywords leadership style as well as leader and leadership when paired with terms such as gender, sex, sex differences, and women. These keywords were searched in the following data bases: Psychological Abstracts (PsycINFO: 1967 to April, 1987), Dissertation Abstracts International (DISS: 1961 to May, 1987), Educational Resources Information Center (ERIC: 1966 to November, 1986), Social Science Citation Index (Social SciSearch: 1971 to October, 1986), Sociological Abstracts (1963 to October, 1986), and a worldwide business and management data base (ABI/INFORM: 1971 to February, 1987). We also searched through the reference lists of numerous review articles, chapters, and books as well as the reference lists of all located studies.

Criteria for including studies in the sample were that (a) the study included one or more measures that assessed task-and interpersonally oriented styles or autocratic versus democratic style; (b) subjects were adults or adolescents from the United States or Canada who were not sampled from abnormal populations; (c) the study assessed the leadership style of at least five people of each sex; and (d) the reported results were sufficient either to calculate a sex-of-subject effect size or to determine the statistical significance or direction of the sex difference. This last criterion eliminated studies that provided only a multiple regression equation in which sex appeared as one of the predictors (e.g., Gustafson, 1982) as well as studies that provided only a multivariate analysis of variance on leadership style combined with other measures (e.g, Martinez, 1982; Rice, Instone, \& Adams, 1984).

Studies were omitted if the people whose leadership style was assessed $^{5}$ had been selected to equalize their status on a personality or attitudinal variable (e.g $\mathrm{g}_{m}$ an index of masculinity or feminity) that probably correlates with both sex and leadership style (e.g., Sirianni-Brantley, 1985; Stake, 1981); accurate estimation of any sex difference in leadership style is not possible from such studies. In addition, studies were rejected if the leadership measure assessed only a narrow aspect of style such as methods of dealing with poorly performing subordinates or managing conflict (e.g., Dobbins, 1986; Dobbins, Pence, Orban, \& Sgro, 1983; Koberg, 1985; Renwick, 1977). If leadership was assessed on several narrow indexes (e.g., Baugher, 1983; Lanning, 1982), these were combined, when appropriate, into a measure of one of the styles considered in this article (e.g., task orientation), based on our independent choices of the indexes that best matched the item content of the most popular measures of the broader style. The indexes were combined using Rosenthal and Rubin's (1986) suggested formula and assuming that the average interindex correlation was .25. This correlation was estimated by averaging the interitem correlations given (or derived from coefficient alphas) for multiple-item style measures used in the studies included in the meta-analysis. These combined measures aggregated five indexes whenever possible (and fewer otherwise). If the report was not sufficiently detailed to allow such combinations, the study was eliminated (e.g., Hughes, Copeland, Ford, \& Heidt, 1983; Moore, Shaffer, Goodsell, \& Baringoldz, 1983).

Studies were also eliminated if the only measures of leadership style assessed ideal rather than actual style (e.g., Arcy, 1980). Studies were omitted if they assessed, not people's naturally occurring styles, but the impact of treatments designed to instill a certain leadership style (e.g., Crudge, 1983; Hall, 1983; Heft \& Deni, 1984). Finally, we excluded studies of T groups, encounter groups, and therapy groups (e.g., Hurst, Stein, Korchin, \& Soskin, 1978), because their measures of leader behavior reflected a tradition quite different from that of the other leadership style research we located. Application of these criteria yielded 162 studies reported in 161 documents (see Appendix).

\footnotetext{
${ }^{5}$ References to people whose leadership style was assessed (and, for brevity, sometimes merely to people) in this article designate leaders only in organizational and laboratory studies; in assessment studies, people not selected for leadership (e.g., samples of undergraduates or nonmanagerial employees of business firms) responded to measures of leadership style.
} 


\section{Variables Coded From Each Study}

The following general information was coded from each report: (a) date of publication; (b) publication form (journal article; other published document; dissertation or master's thesis; other unpublished document); (c) percentage of male authors; (d) sex of first author; (e) number of observations; ${ }^{6}(\boldsymbol{f})$ level of data aggregation (i.e., number of observations aggregated into each data point in the study's statistical analysis) ${ }^{7}$ (g) confounding of male-female comparison with variables such as seniority, education, and age (controlled via matching; known to be confounded on some variables; unknown whether confounded and confounding likely; unknown whether confounded and confounding unlikely), ${ }^{8}$ (h) type of study (organizational; assessment; laboratory); (i) type of setting or subject population (see Table 3 for categories); and ( $j$ ) size of group or organization in which leadership occurred (laboratory group of given size; small organization, defined as less than 500 long-term participants; large organization; mixed or unknown size of organization; people not selected for leadership).

In addition, the following characteristics of the leaders and their roles were coded: (a) level of leadership (first or line; second or middle; third or higher; ambiguous, mixed, or unknown; people not selected for leadership); (b) age of people whose leadership style was assessed; (c) percentage of men among people whose leadership style was assessed (estimated from census tables and other information if not stated in report); (d) percentage of men among subordinates (also estimated if not stated in report; unknown when subordinates not specifically identified); (e) basis of selection of people whose style was assessed (random sample or entire population; unsuccessful random sample, i.e., effort to obtain random sample or entire population but less than $80 \%$ participation; self-selected; unknown); and (f) basis for laboratory leadership (appointed randomly; appointed based on own qualifications; emerged; mixed or unclear).

Finally, the following attributes of the measures of leadership style were coded: (a) type of style assessed (interpersonal; task; interpersonal versus task; democratic versus autocratic); (b) identity of raters (people rated selves; supervisors rated leaders; subordinates rated leaders; peers rated leaders; judges not related organizationally to leaders rated leaders; mixed or unclear); (c) type of rating for style measure (responses to attitude or personality scale; responses to hypothetical leadership situations; presumed observation of leader's behavior without control of behaviors available for observation; actual observation of leader's behavior based on behaviors made available during study) ${ }^{9}$ (d) basis of selection of raters (random sample or entire population; unsuccessful random sample, i.e., effort to obtain random sample or entire population but less than $80 \%$ participation; self-selected; unknown); (e) percentage of men among raters; (f) name of style measure (see Table 2 for categories); and (g) reliability of style measure (reported value; unknown). ${ }^{10}$

These variables were coded independently by the authors, with a median agreement of $97 \%$; "basis of selection of people whose style was assessed" yielded the lowest agreement $(77 \%)$. Disagreements were resolved by discussion.

\section{Variables Constructed From Questionnaire Respondents' Judgments of Leadership Roles}

As noted early in the article we conducted a questionnaire study to generate measures of gender-relevant aspects of the leadcrship roles investigated in the organizational and laboratory studies. To assess the perceived congeniality of the roles for women and men, we calculated sex differences in respondents' self-reported competence to perform each role and interest in performing each role as well as respondents' beliefs about differences in average men's and women's interest in performing each role. ${ }^{11}$ Other measures assessed respondents' judgments of the extent to which each role requires interpersonally oriented ability and task-oriented ability.

Respondents. The sample consisted of 125 female and 181 male Purdue University undergraduates who received partial course credit for participation.

Procedure. Respondents participated in groups of about 15 and in sessions conducted by a female or male experimenter. Each respondent completed one of three versions of a questionnaire that took approximately one hour to complete. Each of the three versions contained brief descriptions of each of the 119 leadership roles investigated in the organizational or laboratory studies. Examples of descriptions used for organizational studies are principal of an elementary school, manager in the communications division of a company, supervisor of state agency caseworkers who determine if particular workers are disabled, and director of intercollegiate athletics in a major university. Examples of descriptions used for laboratory studies are leader of a laboratory discussion group attempting to reach consensus about a decision that all group members had first made individually, manager of a simulated engineering department of a large oil refinery (the manager is given the responsibility of bolstering productivity), and leader of a laboratory group trying to decide which items to take along in order to survive in a desert.

In one version of the questionnaire, respondents judged the roles in response to two questions eliciting self-reports of their competence and interest in relation to each role: (a) How competent would you be as

\footnotetext{
${ }^{6}$ The number of observations (n) for the statistical analysis typically represented either the number of people whose style was assessed or the number of raters (e.g., subordinates) who described the leaders.

${ }^{7}$ For example, each data point might represent 5 observers' ratings of a leader on 10 items, yielding 50 judgments aggregated into each data point. To the extent that measures were based on multiple judgments of leaders' styles, they should yield more reliable estimates of sex differences, in the manner that the number of items in a test relates to the reliability of the total test (e.g., Ghiselli, 1964).

${ }^{8}$ Most organizational studies examined occupants of a given role (e.g., elementary school principals), but a few examined broader classifications of managers (e.g., middle managers of an organization). Even when occupants of the identical role were examined, the equivalence of the men and women in terms of attributes such as age, education, and job seniority is not ensured. Therefore, this aspect of our coding scheme took account of confounding between sex and other attributes of leaders. Some organizational and assessment studies did use samples of men and women who were matched on various attributes, and other studies included data revealing the presence or absence of confounding. When such data were absent in organizational studies, we ordinarily coded confounding as unknown and likely. However, when such data were absent and the people whose style was assessed were students, we coded confounding as unknown and unlikely.

${ }^{9}$ The following list provides an example of the standard measures classified into each category: responses to attitude or personality scale, Least Preferred Co-Worker; responses to hypothetical leadership situations, Leadership Effectiveness and Adaptability Description; presumed observation of leader's behavior without control of behaviors available for observation, Leader Behavior Description Questionnaire; observation of leader's behavior based on behaviors made available during study, Interaction Process Analysis. See Table 2 for information about these measures.

${ }^{10}$ The reliability of the measure was reported for only $14 \%$ of the sex comparisons, precluding any corrections or weighting based on reliability information.

"In this article, the term respondents designates people who participated in the questionnaire study and not those who participated in the studies included in the meta-analysis.
} 
a [role description given]? and (b) How interested would you be in becoming a [role description given]? For the competence question, respondents were told to assume that they could obtain required training or education, and for the interest question, they were told that they had obtained the training or education. In a second version of the questionnaire, respondents judged the roles in response to two questions assessing their beliefs about women's and men's interest in the roles: (a) How interested would the average woman be in becoming a [role description given]? and (b) How interested would the average man be in becoming a [role description given]? These respondents were told to assume that these average women and men could obtain required training or education. In a third version of the questionnaire, respondents judged the roles in response to two questions assessing their beliefs about the abilities each role required: (a) How much ability to cooperate and get along with other people is needed to be an effective [role description given]? and (b) How much ability to direct and control people is needed to be an effective [role description given]?

All ratings were made on 15 -point scales. Each version of the questionnaire was divided into two parts, both of which elicited respondents' judgments of all of the roles in relation to one of the questions. The order of the two parts was counterbalanced. Within each part, the descriptions of the behaviors appeared in one of two random orders.

Analysis of ratings. For the two questions in the first version of the questionnaire, mean scores for each role were computed separately for female and male respondents. For each role, the female respondents' mean was subtracted from the male respondents' mean to yield a mean sex difference, which was standardized by dividing it by the pooled (within-sex) standard deviation. For the two questions in the second version of the questionnaire, the respondents' mean rating of the average woman for each role was subtracted from their mean rating of the average man to yield a mean stereotypic sex difference, which was standardized by dividing it by the standard deviation of the differences between the paired ratings. For the two questions in the third version of the questionnaire, a mean of all the respondents' ratings of each role was calculated. These five mean scores thus described each of the leadership roles in the organizational and laboratory studies. For studies reporting findings aggregated over several roles, ratings of the relevant roles were averaged (e.g., Birdsall, 1980; Gupta, Jenkins, \& Beehr, 1983).

\section{Computation and Analysis of Effect Sizes}

The effect size calculated is $g$, the difference between the leadership style of the men and women, divided by the pooled standard deviation (see Hedges \& Olkin, 1985). A positive sign was given to stereotypic differences (i.e., women more interpersonally oriented, men more task oriented, women more democratic and less autocratic), and a negative sign to counterstereotypic differences.

Multiple effect sizes from single studies. Some studies yielded more than one effect size, most commonly because more than one type of style was assessed. Specifically, if the data report was sufficient, separate effect sizes were calculated when (a) different types of leadership styles were assessed in a study (most frequently interpersonal and task styles); (b) distinctively different measures were used to assess the same type of style (e.g., LBDQ and unique investigator-constructed measure); or (c) different groups of raters responded to the same measure (e.g., leaders, subordinates). Separate effect sizes were also calculated when different groups of leaders were assessed within an organization (e.g., line managers, middle managers) or samples were taken within different types of organizations (e.g., high schools, elementary schools) or different populations of people (e.g $\mathrm{g}_{\rightarrow}$ undergraduates, business school graduate students). If the reported findings were sufficient in laboratory studies, separate effect sizes were calculated when experimental manipulations resulted in (a) leaders obtaining their roles on different bases (e.g., appointed randomly, emerged); (b) groups of subordinates differing in sex composition (e.g., all-male, all-female, mixed sex); or (c) groups working on different tasks (e.g., high vs. low task clarity). Although the computation of more than one effect size from some of the studies created some nonindependence in our data set, the questions we desired to address could not be answered without partitioning the data in these ways. As a result, 31 studies yielded only one effect size, 79 studies yielded two effect sizes, 10 studies yielded three, 19 yielded four, 3 yielded six, and 2 yielded eight, for a total of 329 effect sizes. In addition, 18 studies produced no effect sizes (but did yield a report of the significance or direction of one or more sex comparisons).

Computation of effect sizes. The computation of the $329 \mathrm{gs}$ was based on (a) means and standard deviations or error terms for 149 of the $g$ s, (b) $F$ and $t$ for 80 , (c) correlations or chi-squares for 45 , (d) proportions of men and women manifesting particular styles for $48,{ }^{12}$ and (e) exact $p$ s or level $p$ s (e.g., $p<.05$ ) for 7 . For 41 of the 370 available sex comparisons, the report lacked enough statistical detail to allow an effect size to be computed.

The pooled standard deviation that is the denominator of the effect size was estimated, whenever possible, only from the portion of each study's data entering into the effect size. When the pooled standard deviation was estimated from the mean square error of an analysis of variance (ANOVA), this error term was reconstituted by adding into the sum of squares error all (available) between-groups sums of squares except that for sex. One-way designs are approximated by this procedure, which has been recommended by Hedges and Becker (1986) and Glass, McGaw, and Smith (1981).

To reduce computational error, each of us calculated effect sizes independently. The statistical significance and direction of the sex comparisons were also recorded; this information provided the only record of the sex comparison for studies that provided insufficient information to calculate effect sizes. When the raters who provided the leadership style measure were different from the leaders or managers rated (e.g., they were subordinates) and these ratings were reported separately for the male and female raters, effect sizes were calculated separately for the male and female raters (and the significance and direction of the sex comparison were recorded separately). These additional effect sizes, calculated separately for raters of each sex, supplemented the effect sizes that were combined over both sexes of raters and were used in most analyses.

Analysis of effect sizes. The $g$ s were converted to $d s$ by correcting them for bias (i.e., $g$ 's overestimate of the population effect size, which occurs especially for small samples; see Hedges, 1981; Hedges \& Olkin, 1985). To obtain an overall estimate of the sex difference reported in the available research, we then combined the study outcomes by averaging the $d \mathrm{~s}$. To determine whether each set of $d s$ shared a common effect size (i.e., was consistent across the studies), we calculated a homogeneity statistic, $Q$, which has an approximate chi-square distribution with $k-1$ degrees of freedom, where $k$ is the number of effect sizes (Hedges, 1981; Hedges \& Olkin, 1985).

\footnotetext{
${ }^{12}$ Measures such as Hersey and Blanchard's (1977) Leadership Effectiveness and Adaptability Description (see Table 2), which ordinarily classify leaders into the four quadrants formed by task and interpersonal dimensions of style, were analyzed to yield the proportions of each sex in the two high-task quadrants (for a measure of task-oriented style) and the proportions of each sex in the two high-interpersonal quadrants (for a measure of interpersonally oriented style). These proportions as well as other proportions we encountered were transformed to effect sizes by treating each proportion as the mean of a distribution of 0's and I's (McNemar, 1962). Thus, the effect size was the difference between the male and female proportions divided by the pooled standard deviations of the samples of 0's and l's.
} 
In the absence of homogeneity, we accounted for variability in heterogeneous effect sizes by relating them to the attributes of the studies. To determine the relation between these study characteristics and the magnitude of the effect sizes, both categorical and continuous models were tested (Hedges, 1982a, 1982b; Hedges \& Olkin, 1985). Categorical models, which are analogous to ANOVAs, may show that heterogeneous effect sizes are homogeneous within the subgroups established by dividing studies into classes based on study characteristics. The techniques for calculating categorical models provide a between-classes effect (analogous to a main cffect in an ANOVA) and a test of the homogeneity of the effect sizes within each class. The between-classes effect is estimated by $Q_{\mathrm{B}}$, which has an approximate chi-square distribution with $p-1$ degrees of freedom, where $p$ is the number of classes. The homogeneity of the effect sizes within each class is estimated by $Q_{w_{i}}$, which has an approximate chi-square distribution with $m-1$ degrees of freedom, where $m$ is the number of effect sizes in the class. The tables reporting tests of categorical models also include the mean weighted effect size for each class, calculated with each effect size weighted by the reciprocal of its variance, and an indication of whether this mean differed significantly from the 0.00 value that indicates exactly no sex difference.

The continuous models are least squares simple linear regressions, calculated with each effect size weighted by the reciprocal of its variance. Each such model yields a test of the significance of a predictor as well as a test of model specification, which evaluates whether significant systematic variation remains unexplained in the regression model (Hedges, 1982b; Hedges \& Olkin, 1985). The sum of squares error statistic, $Q_{E}$, which provides this test of model specification, has an approximatc chi-square distribution with $k-p-1$ degrees of freedom, where $k$ is the number of effect sizes and $p$ is the number of predictors (not including the intercept). If correctly specified models are not achieved when implementing continuous models (or homogeneity is not achieved within the classes when implementing categorical models), the results of these analyses cannot be interpreted as confidently as they would otherwise be.

As an alternative analysis to predicting effect sizes using categorical and continuous models, we attained homogencity by identifying outliers among the effect sizes and sequentially removing those that reduced the homogeneity statistic by the largest amount (see Hedges \& Olkin, 1985). Using such a procedure, Hedges (1987) found for several meta-analyses on psychological topics that the removal of up to $20 \%$ of the outliers in a group of heterogeneous effect sizes usually resulted in a high degree of homogeneity. Inspection of the percentage of effect sizes removed to attain homogeneity allows one to determine whether the effect sizes are homogeneous aside from the presence of relatively few aberrant values. Under such circumstances, the mean attained after removal of such outliers may better represent the distribution of effect sizes than the mean based on all of the effect sizes.

\section{Results}

\section{Characteristics of Studies}

Before considering the sex differences reported in studies of leadership style, we examined the characteristics of these studies. Table I shows 18 of these study characteristics aggregated over all of the 370 sex comparisons that we encountered as well as summarized separately within each of the types of leadership style.

As shown by the central tendencies of the characteristics listed in Table 1, studies typically (a) were published relatively recently; (b) were published as dissertations; (c) based the statistical analysis on a moderate number of observations; (d) aggregated a moderate number of observations into each data point; (e) compared the sexes in such a way that some confounding with other variables was likely; and (f) were carried out in organizations. In addition, these studies typically (a) assessed middle managers; (b) assessed adults in their thirties; (c) assessed people in male-dominated roles or from populations with male majorities; (d) assessed leaders with predominantly female subordinates; and (e) unsuccessfully attempted random sampling of the people whose style was assessed or randomly selected them. Finally, the measuring instruments typically (a) had people rate their own leadership styles or had subordinates rate their leaders; and (b) used ratings presumably based on observation of leaders' behavior but without control of the behaviors available for observation.

The means for the last five characteristics represent the variables constructed from questionnaire respondents' judgments of the leadership roles examined in the studies. As shown by these means, women judged themselves as significantly more competent in these leadership roles and as more interested in occupying the roles than men did. In addition, respondents of both sexes judged the average woman more interested in occupying the roles than the average man. ${ }^{13}$ They also judged that the roles required "quite a lot" of both interpersonal and task ability. ${ }^{14}$

When these study characteristics were examined separately within the types of leadership style (see Table 1), notable exceptions to these overall patterns were that (a) journal articles were especially common in studies of autocratic versus democratic style, (b) measures of interpersonal versus task style and democratic versus autocratic style were based more exclusively on self-ratings, and (c) measures of interpersonal versus task stylc were based primarily on responses to attitude scales.

Table 2 lists the measuring instruments that assessed leadership style and names all measures that were used for two or more of the sex comparisons. As Table 2 shows, the majority of the studies used standard instruments; the Leader Behavior Description Questionnaire, which places task and interpersonal orientations on separate dimensions, received the most use. The Least Preferred Co-Worker instrument predominated

\footnotetext{
${ }^{13}$ The greater congeniality of these leadership roles for women compared with men should be interpreted in terms of the distribution of organizational settings given in Table 3 . In particular, a large number of studies in our sample examined clementary school principals, a role our data suggested that women find congenial.

${ }^{14}$ The mean ratings on these 15 -point scales fell in the range anchored by the term "quite a lot." Suggesting that our student respondents were able to discriminate between the interpersonal and task requirements of leadership roles, mean ratings showed that some roles were thought to require considerably more interpersonal than task ability (e.g., "leader of a laboratory discussion group attempting to reach consensus about a decision that all group members had first made individually"; "elected leader of a student organization in a college") and that other roles were thought to require considerably more task than interpersonal ability (e.g., "platoon leader at West Point" and other military roles; "president of a corporation").
} 
Table 1

Summary of Study Characteristics

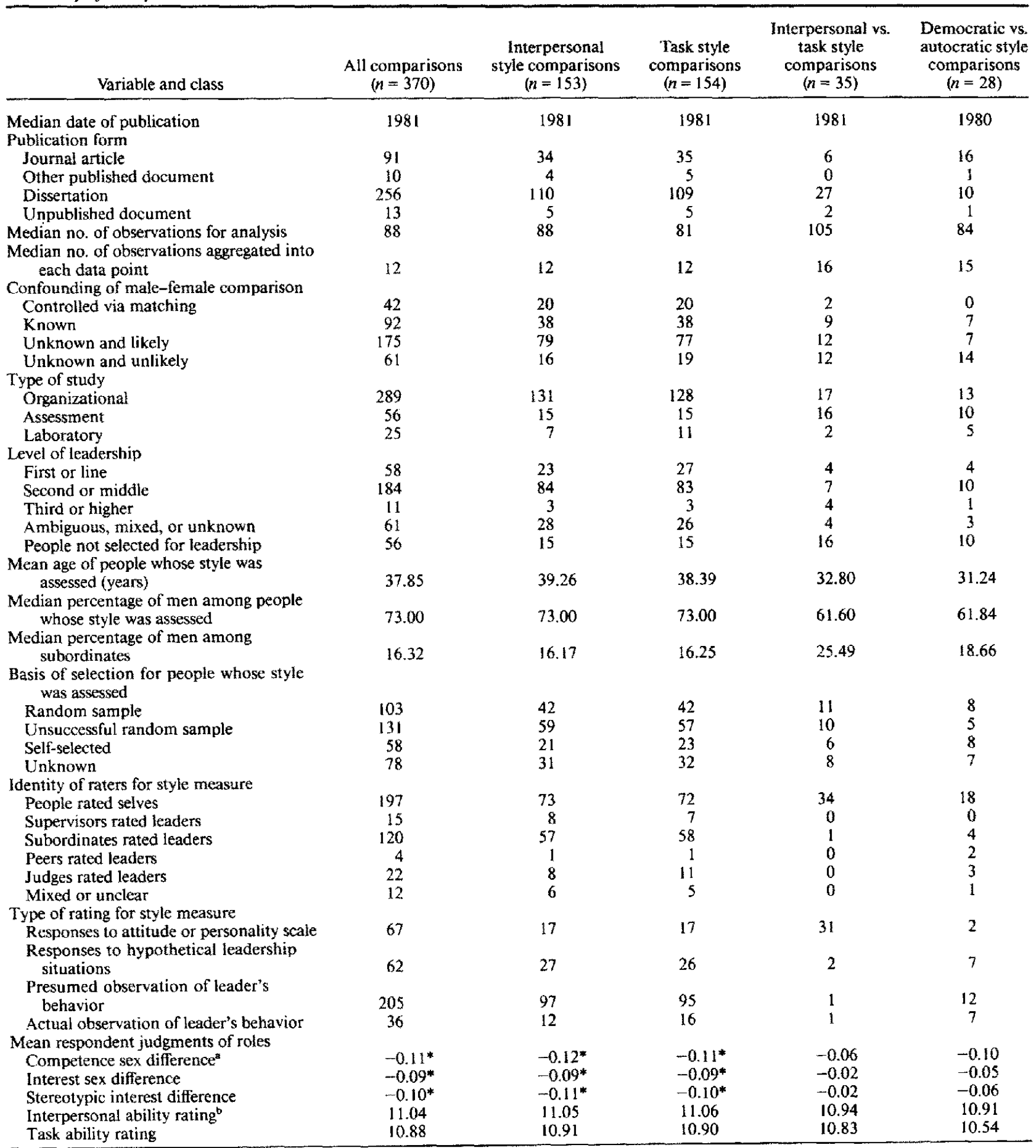

Note. For categorical variables, numbers in table represent frequency of sex comparisons in each class. Summaries of continuous variables are based on reports for which information was available on each variable.

${ }^{a}$ For the first three variables constructed from judgments of the leadership roles, values are positive for differences in the masculine direction (greater male estimates of competence and of interest; ascription of greater interest to average men). ${ }^{b}$ For the last two variables constructed from judgments of the leadership roles, values are larger to the extent that a role was judged to require more interpersonal or task ability (on 15-point scales with 15 indicating high ability)

* Differs significantly ( $p<.05$ or smaller) from 0.00 (exactly no difference). 
among studies placing interpersonal and task orientation on two ends of a single dimension. In contrast, unique measures predominated in studics of democratic versus autocratic style.

Table 3 describes the settings of the organizational studies and the subject populations of the assessment and laboratory studies. Among the organizational studies, educational settings predominated; the greatest number of these studies examined elementary school principals or university administrators. College undergraduates predominated in both the assessment and the laboratory studies.

\section{Overall Sex Differences in Leadership Style}

The summary given in Table 4 allows one to determine if men and women differed in leadership style. An overall sex difference is shown by a mean effect size that differed significantly from the 0.00 value that indicates exactly no difference (i.e., by a confidence interval that did not include 0.00 ). The sign of these means is positive for stereotypic differences and negative for counterstereotypic differences. These means and confidence intervals are given both aggregated over all types of style and computed separately for each style.

In general, leadership styles were slightly gender stereotypic: The weighted mean computed across all types of style was slightly but significantly stereotypic (see Table 4). ${ }^{15}$ However, computed within each type, these means indicated no sex difference for (a) the task comparisons and (b) the interpersonal versus task comparisons. These means indicated stereotypic differences for (a) the interpersonal comparisons (women were more interpersonally oriented) and (b) the democratic versus autocratic comparisons (women were more democratic). Yet the mean effect size for interpersonal style was quite small. The largest overall sex difference was obtained for the democratic versus autocratic comparisons: Sex comparisons for this type of style were significantly more stereotypic than those for each of the other three types of style (as shown by appropriate contrasts; see description of contrast procedure in next subsection). This pattern was similar for the unweighted means, although the task style difference became significant in the counterstereotypic direction (i.e., women were more task oriented). The medians of the effect sizes were similar to the weighted and unweighted means.

As shown by the homogeneity statistics given in Table 4 , the sex comparisons were not homogeneous (i.e., consistent) across the studies. As also indicated in Table 4, the removal of various numbers of outliers allowed homogeneity to be attained. Suggesting relatively stable findings, the procedure climinated small proportions of effect sizes for all of the types of style except the democratic versus autocratic stylc, which required eliminating $22 \%$ to attain homogeneity. The confidence intervals associated with the weighted means after outlier removal showed that the overall tendencics for women to be more interpersonally oriented, more task oriented, and more democratic than men were all significant.

There is no completely satisfactory method to compute a mean effect size that takes into account the nonsignificant comparisons that could not be represented as effect sizes because of a lack of sufficient information. Nevertheless, one possible solution is to give these comparisons the value of 0.00 (indicating exactly no sex difference). ${ }^{16}$ When this step was taken, the mean unweighted effect sizes (see means reported in Table 4 under "All reports") became slightly smaller than the unweighted means (before outlier removal) that omitted these 0.00 values, but the pattern was the same (i.e., women were more interpersonally oriented, more task oriented, and more democratic).

Table 4 also reports the proportion of sex comparisons that were stereotypic in direction. These proportions differed significantly from .50 , the proportion expected under the null hypothesis, for the interpersonal, task, and democratic versus autocratic comparisons ( $p s<.01$ or smaller). Consistent with the pattern we have already described, these differences were counterstereotypic for the task style and stereotypic for the interpersonal and the democratic versus autocratic styles.

\section{Accounting for Variability in the Effect Sizes}

Categorical and continuous models were fitted to the effect sizes following Hedges and Olkin's (1985) statistical procedures (see Method).

Test of our major hypothesis. To test our hypothesis that sex differences in leadership style are less stereotypic in organizational settings than in other settings, we classified the effect sizes into the three types of studies: organizational, assessment, and laboratory. Consistent with the significant between-classes effects for type of study shown in Table 5 , the expected pattern was obtained for interpersonal style and task style. For interpersonal style, a priori comparisons among the mean weighted effect sizes for the three classes of studies (see Hedges \& Becker, 1986; Hedges \& Olkin, 1985) showed that the sex difference for the organizational studies was significantly less stereotypic than that for the assessment studies $(p<.01)$ or the laboratory studies $(p<.001)$. For task style, these comparisons also showed that the sex difference for the organizational studies was significantly less stereotypic than that for the assessment studies $(p<.05)$ or the laboratory studies $(p<.025)$. For measures of interpersonal versus task style as well as democratic versus autocratic style, type of study had no significant effect. The significant effect that type of study produced when all the effect sizes were analyzed thus reflects primarily the trends observed for the interpersonal and task styles.

Table 5 also reports categorical models that were based on classifying the effect sizes into the four types of style and were computed within each type of study (i.e., organizational, assessment, laboratory). The significant between-styles effect for the organizational studies primarily reflects the relatively large mean for the democratic versus autocratic style, and the significant effect for the assessment studies primarily reflects the relatively large means for the interpersonal and the democratic versus autocratic styles. The nonsignificance of the betweenstyles effect for the laboratory studies suggests that leadership

\footnotetext{
${ }^{15}$ The weighted means were computed by weighting each known effect size by the reciprocal of its variance (Hedges \& Olkin, 1985), a procedure that gives more weight to effect sizes that are more reliably estimated.

${ }^{16}$ Because these 0.00 values do not ordinarily provide accurate estimates of the true effect sizes, they were omitted from further analyses.
} 
Table 2

Summary of Leadership Style Measures Used in Studies

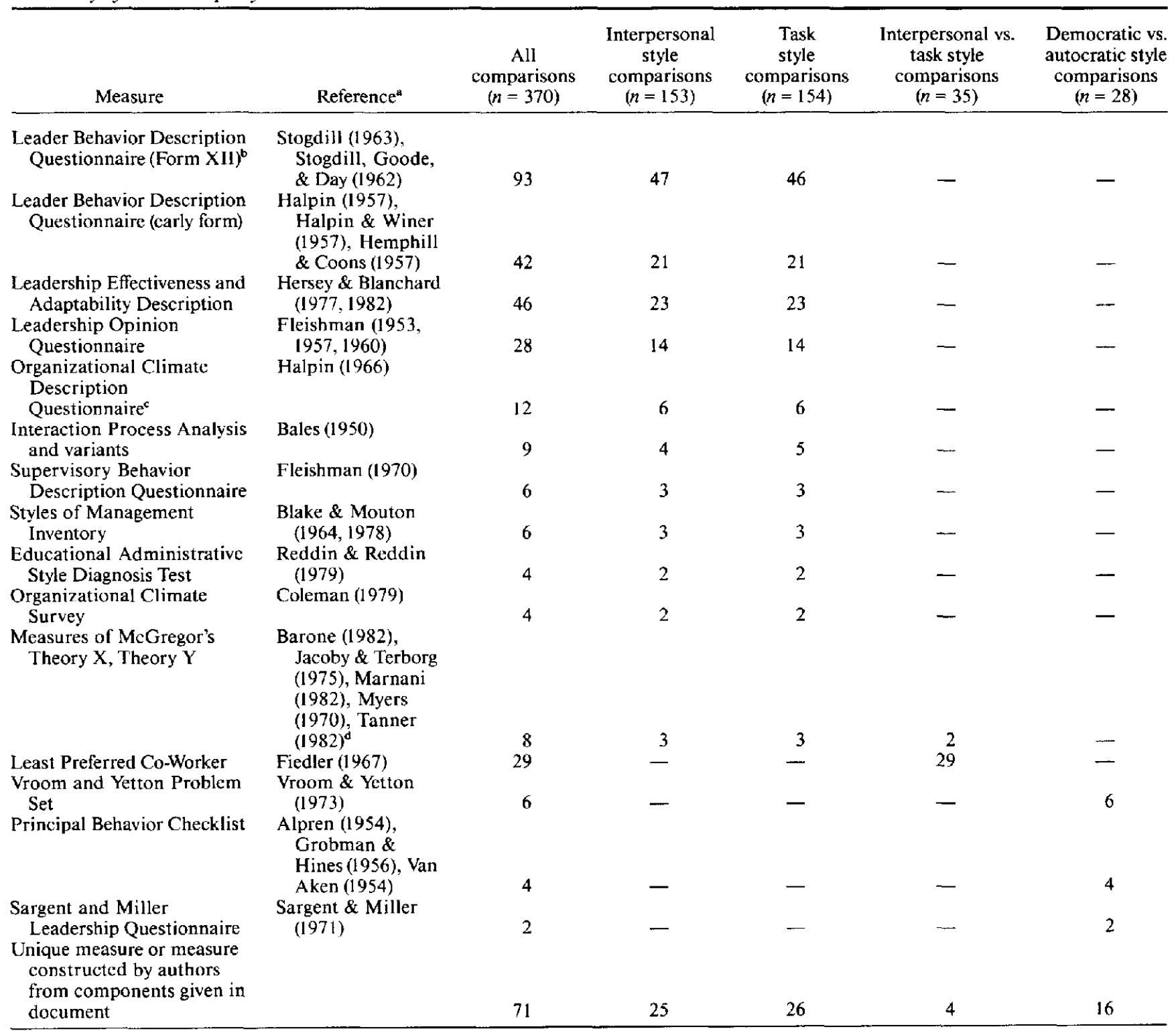

a References listed provide information regarding the development of each measure of style. ${ }^{b}$ Used consideration and initiation of structure scales. ${ }^{\mathrm{c}}$ Used consideration and production emphasis scales. 'Scales developed by authors listed to assess McGregor's (1960) Theory X and Theory $\mathrm{Y}$ concepts.

styles were stereotypic in laboratory studies regardless of the type of style assessed. Although the number of laboratory studies on leadership style is unfortunately quite small, the relative consistency of this stereotypic trend across the types of style lends confidence to our generalization that leaders' behavior is somewhat gender stereotypic in experimental settings.

Models involving characteristics of research report. The sex of the authors of the research reports also related to the effect sizes; female authors obtained more stereotypic findings on the whole ( $p<.001$ for categorical model). Yet when the effect sizes were examined within the four types of style, this overall trend was intact only for the interpersonal and the democratic versus autocratic styles ( $p$ s $<.001$ for categorical models). To the extent that women especially value interpersonally oriented and democratic styles, this finding suggests a tendency for authors to portray their own sex favorably. Eagly and Carli (1981) and Wood (1987) reported this tendency in earlier meta-analyses.

As shown by one of the models given in Table 6 , date of publication related significantly to all of the sets of effect sizes. On an overall basis, sex differences were more stereotypic in the more recent studies, and this trend was also obtained for the interpersonal and the task styles, which predominated among 
Table 3

Summary of Setting or Subject Population for Organizational, Assessment, and Laboratory Studies

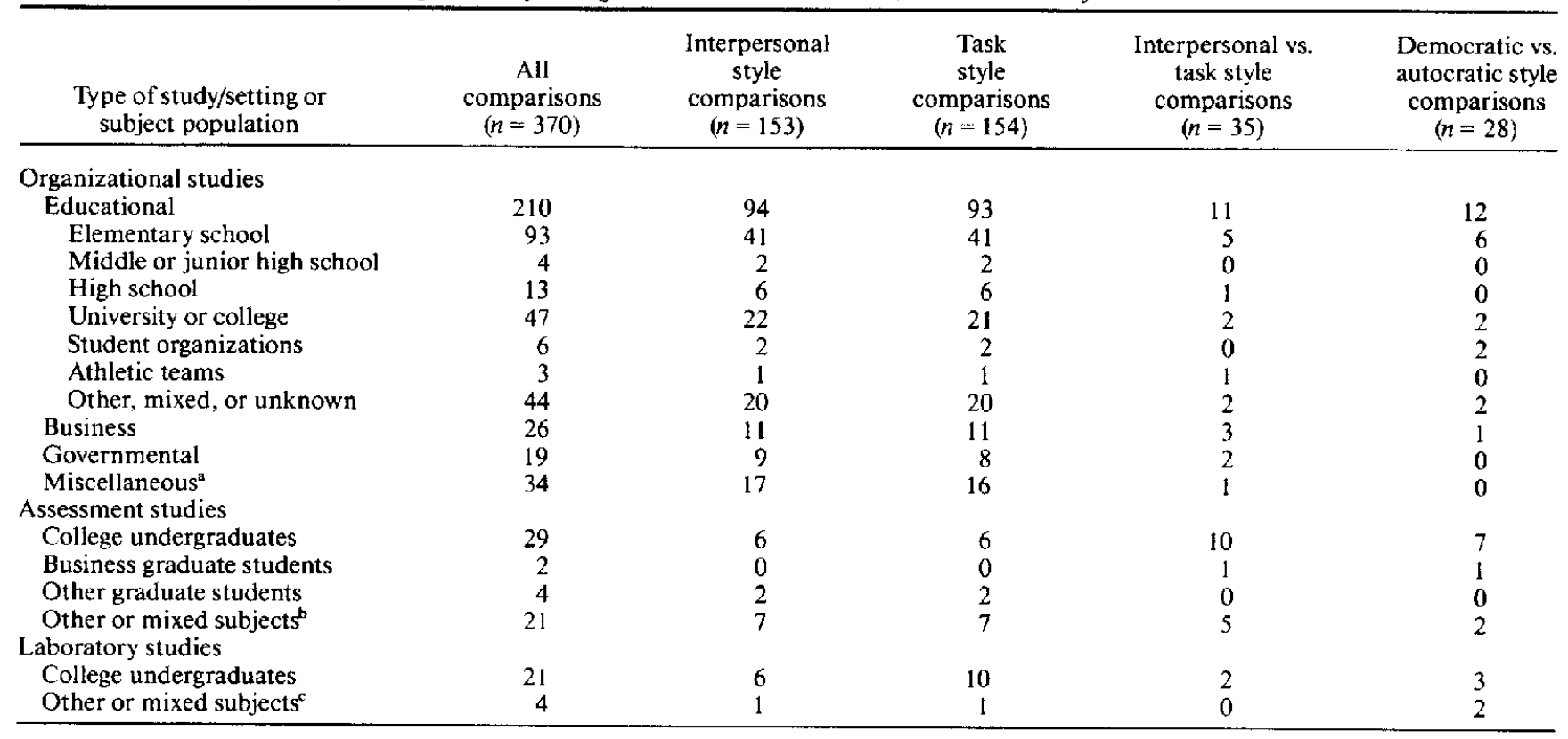

a Includes military, religious, hospital, and other settings. ${ }^{\mathrm{b}}$ Includes candidates for managerial positions, participants in management training programs, and nonmanagerial employees of business firms. " Includes graduate students and mixed samples of undergraduate and graduate students.

our effect sizes. However, sex differences became less stereotypic over time in our two smaller samples of effect sizes, namely interpersonal versus task style and democratic versus autocratic style. This lack of consistency over the four types of style and the confounding of publication date with various study attributes clouds interpretation of these secular trends. ${ }^{17}$

Among the characteristics of the research reports that did not relate to the magnitude of the sex differences is whether the report was published (i.e., journal article or other published document) or unpublished (i.e., dissertation or other unpublished document). Although it is common in meta-analyses that effects are larger in published than unpublished studies (see Glass, McGaw, \& Smith, 1981), this relation is often absent in meta-analyses of sex differences in social behavior, presumably because these reports are often incidental to studies' main hypotheses and therefore have little impact on publishability (see Eagly, 1987).

Models involving characteristics of studies' methods. Most aspects of the studies' methods that we coded either did not relate to the effect sizes or related relatively weakly. Furthermore, interpretation of those few relations that did prove significant was often hampered by skewed distributions of many of these features (see Table 1) as well as by (a) confounding between these features and (b) relatively small numbers of effect sizes for two of the styles (i.e., interpersonal vs. task and democratic vs. autocratic). Nonetheless, we note some of the many analyses we performed.

We were particularly interested, for example, in whether studies in which sex was known to be confounded with personal attributes such as age and job seniority (or was likely to have been so confounded) would produce more stereotypic sex comparisons. We did not obtain such tendencies. Nor did sex comparisons appear to be more stereotypic in self-selected samples or in samples for which random selection was seriously compromised. Furthermore, sex comparisons did not become less stereotypic when the rating underlying the style measure was more directly linked to behavior and therefore presumably less vulnerable to biases based on gender stereotypes. The impact of the specific measuring instrument used to assess style (see Table 2) was difficult to evaluate because of small sample sizes for most measures and the confounding of measures with characteristics of the instruments such as the identity of the raters.

The identity of the raters who provided the data for the style measure did have some impact on sex differences in both interpersonal and task orientation. Most of the measures of these two styles were based on self ratings or subordinate ratings (see Table 1), and self ratings were significantly more stereotypic than subordinate ratings for interpersonal style $(p<.01)$ and task style $(p<.001)$. For the two other types of style, skewed

\footnotetext{
${ }^{17}$ Neither on an overall basis nor for interpersonal and task styles do these findings support the idea that social change or similar factors have caused leaders to become less stereotypic in their styles. Yet a variant of the social change interpretation suggests that in earlier years when women typically faced more formidable barriers to attaining leadership roles, the women in these roles may have been even more highly selected for similarity to their male counterparts. This interpretation is consistent with an increase in the tendency for leaders to use stereotypic styles.
} 
Table 4

Summary of Sex Differences in Leadership Style

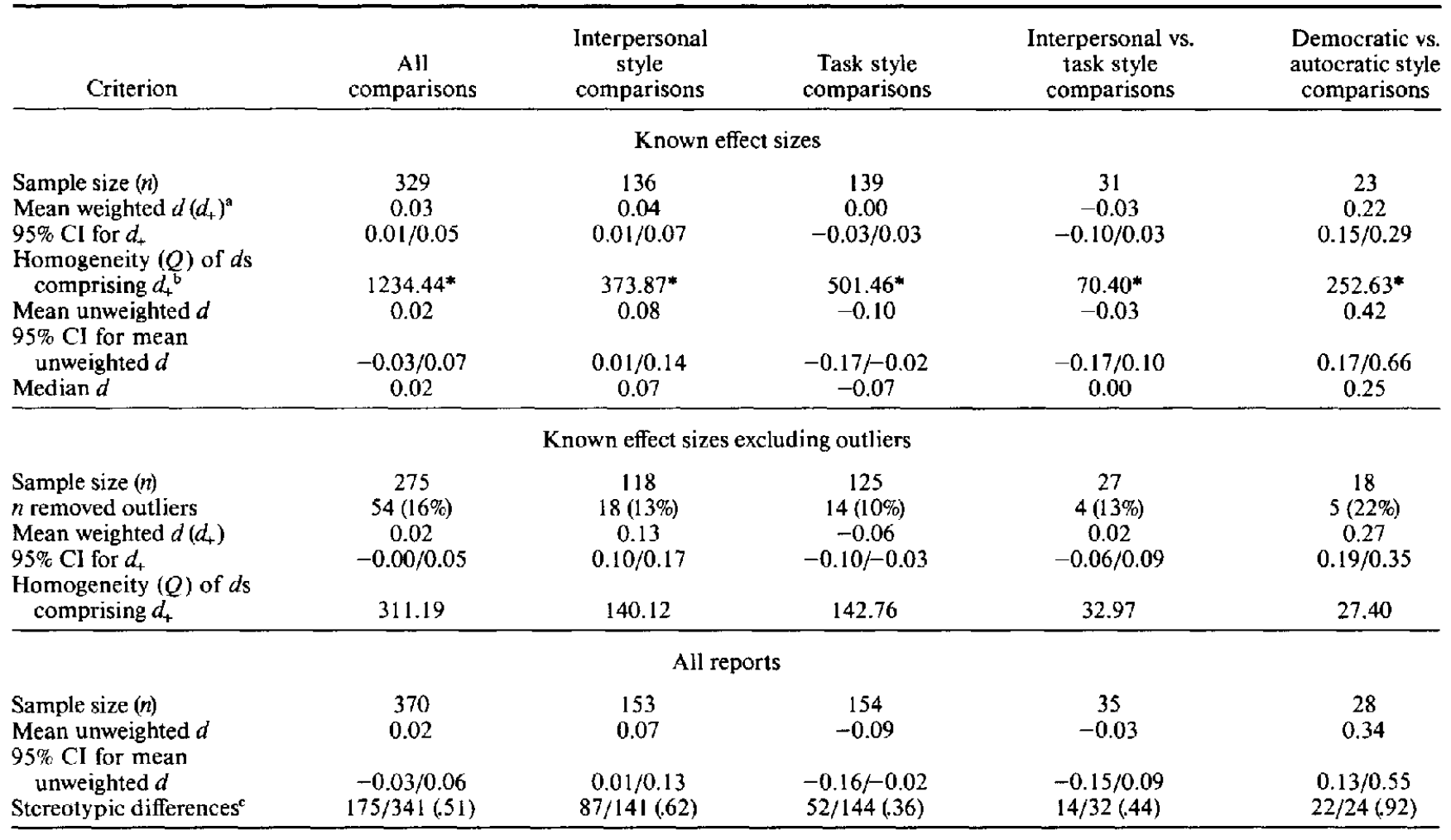

Note. When all reports were included, a value of 0.00 (exactly no difference) was assigned to sex differences that could not be calculated and were reported as nonsignificant. Effect sizes were calculated for all significant differences. Effect sizes are positive for differences that are stereotypic and negative for differences that are counterstereotypic. $\mathrm{CI}=$ confidence interval; $d=$ effect size; $d_{+}=$mean weighted effect size; $Q=$ homogeneity of effect sizes.

${ }^{a}$ Effect sizes were weighted by the reciprocal of the variance. ${ }^{b}$ Significance indicates rejection of the hypothesis of homogeneity. ${ }^{c}$ Frequencies are number of differences in the stereotypic direction divided by the number of differences of known direction. The proportion appears in parentheses.

$* p<.001$.

distributions of the raters' identity precluded meaningful analyses. In addition, sex of the raters showed no relation to the effect sizes.

As shown in one of the models given in Table 6, the level of aggregation of the style measure related significantly to the total set of effect sizes as well as to the effect sizes for the task, interpersonal versus task, and autocratic versus democratic styles. Specifically, as the number of judgments underlying each data point increased, women became relatively more task oriented than men and relatively more democratic. Thus, in the case of the task and the democratic versus autocratic styles, the overall tendencies for women to be more task oriented and more democratic than men (see Table 4 ) were more pronounced in studies using measures that can be presumed to be more reliable by virtue of their higher level of aggregation.

Models involving characteristics of social settings and leadership roles. Organizational size had little effect on the sex differences, but information necessary to code this variable was often missing from the reports. The organizational level of leaders had little impact on the effect sizes except for task style: A tendency for men to be more task oriented than women obtained for first-level (i.e., line) managers reversed slightly for the midlevel managers ( $p<.001$ for contrast). The basis by which leaders were selected in laboratory studies also related to the effect sizes: Leaders who were appointed on a random basis or on the basis of their own qualifications behaved more stereotypically than leaders who emerged on their own $(p<.025$ for categorical model).

The percentage of men among the people whose style was assessed related significantly to sex differences in both the interpersonal and the democratic versus autocratic styles (see Table 6). To the extent that men predominated, the tendencies weakened for women (vs. men) to show more concern about interpersonal relations and to be more democratic.

Two additional variables - the percentage of men among leaders' subordinates and the age of the people whose style was assessed-related significantly to the effect sizes for some of the styles within the organizational sample, which maintained moderate numbers of effect sizes for these analyses. Specifically, larger proportions of male subordinates were associated with male leaders being more task-oriented than female leaders $(p<$ .001 ), but more interpersonally oriented on interpersonal ver- 
sus task measures $(p<.05)$ and less democratic $(p<.01){ }^{18}$ Also within the organizational studies, age was a significant predictor of sex differences in task and interpersonal styles: Older leaders were more stereotypic in their interpersonal style but less stereotypic in their task style $(p s<.001)$. However, interpretation of these relations involving age and the sex distribution of subordinates was limited by relatively large amounts of missing data as well as by confounding of these variables with types of studies (i.e., organizational, assessment, laboratory).

Models involving gender congeniality of leadership roles. As shown by the analyses using our gender congeniality measures as predictors (see Table 6), questionnaire respondents' judgments of the leadership roles related significantly to sex differences in task style. In general, leaders of each sex were especially task oriented when their role was viewed as congenial to their gender. Specifically, these effect sizes were larger (i.e., positive, indicating men were more task oriented than women) to the extent that (a) male (compared with female) respondents rated themselves as more competent in the role, (b) male respondents rated themselves as more interested in occupying the role, (c) respondents of both sexes judged the average man more interested in occupying the role than the average woman, and (d) respondents of both sexes judged that the role required relatively little interpersonal ability. Similarly, these effect sizes were smaller (i.e., negative, indicating women were more task oriented than men) to the extent that the roles were more congenial to women on these indexes. Because respondents' judgments of the leadership roles were significantly related only to sex differences in task style, the significant relations obtained when all the effect sizes were analyzed reflected primarily the task style findings. ${ }^{19}$

\section{Discussion}

\section{Interpersonal and Task Styles}

Our major hypothesis was that stereotypic sex differences would be less pronounced in organizational studies than in assessment or laboratory studies. Indeed, this hypothesis was confirmed for both interpersonal and task styles. These findings support our arguments that the criteria organizations use for selecting managers and the forces they maintain for socializing managers into their roles minimize tendencies for the sexes to lead or manage in a stereotypic manner. Yet these data also suggest that people not selected or trained for leadership roles do manifest stereotypic leadership behavior when placed in these roles, as shown by the data from the assessment and the

\footnotetext{
${ }^{18}$ The sex of subordinates may affect the behavior of leaders of both sexes more than it affects sex differences in leaders' styles. Consistent with this suggestion, Carli (1989) found in a laboratory experiment that subjects used more aggressive and direct styles of influence when dealing with men than with women.

${ }^{19}$ Numerous categorical and continuous models thus yielded significant prediction of the effect sizes. However, homogeneity was rarely attained within the classes of the categorical models nor were correctly specified models achieved for the continuous models.
} 
Table 6

Continuous Models for Sex Differences in Leadership Style

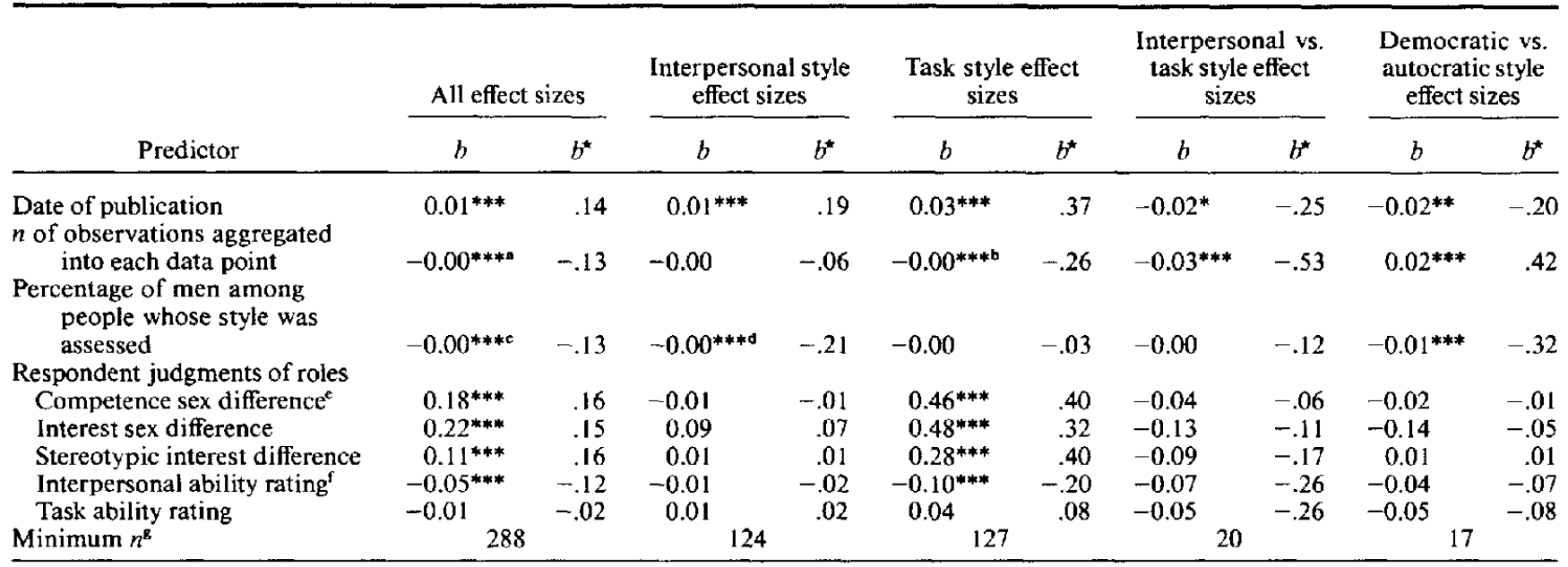

Note. Models are weighted least squares simple linear regressions calculated with weights equal to the reciprocal of the variance for each effect size. Effect sizes are positive for differences that are stereotypic and negative for differences that are counterstereotypic. $b=$ unstandardized regression coefficient. $b^{\star}=$ standardized regression coefficient.

${ }^{\mathrm{a}} b=-0.0092, S E(b)=.000016 .{ }^{\mathrm{b}} b=-0.0017, S E(b)=.000029 . \quad{ }^{\mathrm{c}} b=-0.0028, S E(b)=.000052 .{ }^{\mathrm{d}} b=-0.0040, S E(b)=.000099 . \quad{ }^{\mathrm{c}} \mathrm{For}$ the first three variables constructed from judgments of the leadership roles, values are positive for differences in the masculine direction (greater male estimates of competence and of interest; ascription of greater interest to average men). 'For the last two variables constructed from judgments of the leadership roles, values are larger to the extent that a role was judged to require more interpersonal or task ability. ${ }^{B} n$ varied across the analyses because of missing data (e.g., the absence of judgments of the leadership roles for the assessment studies).

$* p<.05$. $^{* *} p<.01$. ${ }^{* * *} p<.001$.

laboratory studies. Moreover, our claim that selection criteria lessen sex differences is strengthened by the finding that those few laboratory leaders who gained their positions through emergence did not manifest the stereotypic styles of laboratory leaders who were appointed. Evidently sex differences were leveled even by the implicit leader selection criteria of initially leaderless groups.

When we ignored whether the sex comparisons were from organizational, assessment, or laboratory studies (see Table 4), sex differences in interpersonal and task styles were quite small, with overall trends toward women being more concerned about both maintenance of interpersonal relationships and task accomplishment. In view of these trends, it is not surprising that measures placing interpersonal and task orientation on the ends of a single dimension produced no sex difference in any of the overall summaries. On such bipolar measures, the stereotypic interpersonal sex difference and the counterstereotypic task difference would cancel one another, resulting in no difference.

Given the variety of settings, roles, and measures encountered in this research, the sex comparisons for the task and interpersonal styles were expected to be inconsistent across the studies. Yet the removal of relatively small numbers of the effect sizes $(10 \%$ to $13 \%$ ) produced homogeneous sets of effect sizes consistent with description in terms of single means. This aspect of the findings lends some confidence to our statements that if we take the entire research literature into account, women's leadership styles emphasize both interpersonal relations and task accomplishment to a slightly greater extent than men's styles.

\section{Democratic Versus Autocratic Style}

The strongest evidence we obtained for a sex difference in leadership style occurred on the tendency for women to adopt a more democratic or participative style and for men to adopt a more autocratic or directive style. Moreover, this sex difference did not become smaller in the organizational studies, as did the differences in the interpersonal and task styles. Although the overall mean weighted effect size $\left(d_{+}=0.22\right)$ was not large, the mean became larger once outliers were removed $\left(d_{+}=0.27\right)$, and $92 \%$ of the available comparisons went in the direction of more democratic behavior from women than men. Despite this impressive consistency in the direction of the sex difference, the effect sizes themselves were quite heterogeneous, requiring the removal of $22 \%$ to obtain a set that did not reject the hypothesis of homogeneity. Yet substantial inconsistency across the studies is not unexpected for this type of style in view of the tendency for investigators to construct unique measures and not to rely on standard instruments, as did most investigators of the other types of leadership style that we reviewed (see Table 2).

Our interpretation of the sex difference in the extent to which leaders behave democratically versus autocratically is necessarily speculative, but follows from some of the considerations that we presented early in this article (see Reasons to Expect the Presence of Sex Differences in Leadership Style). We thus argued that women and men recruited into leadership roles in organizations may not be equivalent in personality and behavioral tendencies, even though they satisfy the same selection criteria. In particular, we noted that women's social skills might enable 
them to perform managerial roles differently than men. Interpersonal behavior that is skillful (e.g., in terms of understanding others' feelings and intentions) should facilitate a managerial style that is democratic and participative. Making decisions in a collaborative style requires not only the soliciting of suggestions from one's peers and subordinates, but also the preservation of good relationships with them when evaluating and perhaps rejecting their ideas. The give-and-take of collaborative decision making introduces interpersonal complexity not encountered by leaders who behave in an autocratic or directive manner. This interpretation is supported by research showing that teachers who lacked social skills, as indexed by their relative inability to decode nonverbal cues, had more autocratic attitudes and were generally more dogmatic (Rosenthal, Hall, DiMatteo, Rogers, \& Archer, 1979).

Another perspective on the democratic-autocratic sex difference acknowledges the attitudinal bias against female leaders that we considered in the beginning of the article. The skepticism that many people have expressed concerning women's capabilities in managerial and leadership roles may be exacerbated by any tendency for women in these roles to take charge in an especially authoritative manner. Placating subordinates and peers so that they accept a woman's leadership may to some extent require that she give them input into her decisions and allow some degree of control over these decisions. Moreover, to the extent that women leaders have internalized to some degree the culture's reservations about their capability for leadership, they may gain confidence as leaders by making collaborative decisions that they can determine are in line with their associates' expectations. Thus, proceeding in a participative and collaborative mode may enable many female leaders to win acceptance from others, gain self-confidence, and thereby be effective. Because men are not so constrained by attitudinal bias, they are freer to lead in an autocratic and nonparticipative manner should they so desire. ${ }^{20}$

\section{The Impact of Gender Congeniality of Leadership Roles and Sex Distribution of Role Occupants}

Our findings suggested that leaders of each sex emphasized task accomplishment when they were in a leadership role regarded as congruent with their gender. Thus, only the sex differences in task style were significantly correlated with the tendency for the leadership roles to be regarded as more congenial for men or women, as indexed by our questionnaire respondents' judgments (see Table 6). Male leaders tended to be more task oriented than female leaders to the extent that a leadership role was more congenial to men; female leaders tended to be more task oriented than male leaders to the extent that a leadership role was more congenial to women. Furthermore, women tended to be more task oriented than men in leadership roles that are feminine in the sense that our respondents judged they require considerable interpersonal ability. ${ }^{21}$

These findings suggest that being out of role in gender-relevant terms has its costs for leaders in terms of some decline in their tendency to organize activities to accomplish relevant tasks. Because our meta-analytic data are not informative concerning the mediation of these effects, these provocative findings should be explored in primary research. Perhaps people who are out of role lack (or are perceived to lack) the skills necessary to organize the task-relevant aspects of their environment. Out-of-role leaders may be somewhat deficient in the knowledge and authority required to organize people and resources to accomplish task-relevant goals.

The extent to which leadership roles were male dominated numerically also related to sex differences in leadership style. Specifically, the tendencies for female leaders to be more interpersonally oriented and more democratic than male leaders weakened to the extent that a role was male dominated. Thus, when women were quite rare in leadership roles and therefore tended to have the status of token in organizations or groups, they abandoned stereotypically feminine styles characterized by concern for the morale and welfare of people in the work setting and consideration of these people's views when making decisions. These findings suggest that women may tend to lose authority if they adopt distinctively feminine styles of leadership in extremely male-dominated roles. Women who survive in such roles probably have to adopt the styles typical of male role occupants.

\section{Conclusion}

The view, widely accepted by social scientists expert on leadership, that women and men lead in the same way should be very substantially revised. Similarly, the view, proclaimed in some popular books on management, that female and male leaders have distinctive, gender-stereotypic styles also requires

\footnotetext{
${ }^{20}$ A subsequent meta-analysis by Eagly, Makhijani, and Klonsky
} (1990) showed that subjects evaluate autocratic behavior by female leaders more negatively than they evaluate the equivalent behavior by male leaders. An additional consideration in interpreting the democratic-autocratic sex difference is that measures of this type were based primarily on leaders' self-reports (see Table 1), and, at least for task and interpersonal styles, leaders' self-reports were more stereotypic than subordinates' reports on leaders (see Results). Thus, it is possible that the tendency for women to be more democratic than men was exaggerated somewhat by the reliance on leaders' self-reports in these studies. Yet, because the sex comparisons for the democratic versus autocratic style were more stereotypic than the subset of sex comparisons for the interpersonal and task styles that were based on self-reports, it is very unlikely that this methodological feature of the democratic-autocratic studies fully accounts for the sex difference in this type of style.

${ }^{21}$ We explored whether a tendency for laboratory leadership roles to be more congenial for men might have contributed to the more stereotypic task styles found in laboratory (vs. organizational) studies (see Table 4). Indeed, our questionnaire respondents judged the laboratory (vs. organizational) roles as somewhat more congenial to men on the measures of sex differences in competence and interest and on the measure of stereotypic sex differences in interest ( $p s<.05$ or smaller). In addition, the laboratory roles were judged to require less interpersonal ability than organizational roles but, contrary to the idea that the laboratory roles were relatively masculine, they were also judged to require less task ability ( $p s<.001$ ). Thus, there was some degree of confounding between the type of study and the gender congeniality of the roles. Nonetheless, the significant relations between the congeniality measures and sex differences in task style reported in Tablc 6 remained significant when examined within the set of organizational studies. 
revision. Our quantitative review has established a more complex set of findings. Although these findings require further scrutiny before they should be taken as definitive, the agreement of these findings with our role theory framework substantiates our interpretation of them. Thus, consistent with research on sex differences in numerous social behaviors (Eagly, $1987 ;$ Hall, 1984), we have established that leadership style findings generated in experimental settings tend to be gender stereotypic. Indeed, these findings concur with the generalizations of those narrative reviewers who noted that male and female leaders often differ in laboratory experiments (Brown, 1979; Hollander, 1985). In such settings, people interact as strangers without the constraints of long-term role relationships. Gender roles are moderately important influences on behavior in such contexts and tend to produce gender-stereotypic behavior (see Eagly, 1987). In addition, somewhat smaller stereotypic sex differences were obtained in assessment studies, in which people not selected for leadership responded to instruments assessing their leadership styles. Because respondents not under the constraints of managerial roles completed questionnaires in these studies, some tendency for leadership styles to appear stereotypic was expected from the perspective of our social role framework.

When social behavior is regulated by other, less diffuse social roles, as it is in organizational settings, behavior should primarily reflect the influence of these other roles and therefore lose much of its gender-stereotypic character. Indeed, the findings of this meta-analysis for interpersonal and task styles support this logic. Nonetheless, women's leadership styles were more democratic than men's even in organizational settings. This sex difference may reflect underlying differences in female and male personality or skills (e.g, women's superior social skills) or subtle differences in the status of women and men who occupy the same organizational role. Deciding among the various causes that we have discussed would require primary research targeted to this issue.

The magnitude of the aggregate effect sizes we obtained in this meta-analysis deserves comment. When interpreting effect sizes, reviewers should take the methods of the studies into account, and, as Glass, McGaw, and Smith (1981) argued, they should avoid applying numerical guidelines to identify effect sizes as small or large. One feature of research on leadership style that is especially relevant to interpreting the magnitude of our aggregate effect sizes is that investigators face many barriers to achieving well-controlled studies. In organizational studies, the environments in which managers carry out their roles are quite diverse, even within a single organization. Because managers' leadership styles are evaluated either by themselves or by their associates, the various managers in a study are not necessarily evaluated by the same standard. Although more control of environmental influences can be achieved in laboratory studies of leadership (e.g., all leaders can be observed in a similar social setting), even these studies are relatively uncontrolled because each leader interacts with a unique group of followers. Counterbalancing the greater control of environmental factors in laboratory than organizational studies is the less rigorous selection of research participants for laboratory research and the resulting greater variability of leadership style within each sex. In general, uncontrolled variability in both organizational and laboratory studies of leadership would inflate the standard deviations that are the denominators of the effect sizes and thereby decrease the magnitude of these effect sizes. As a consequence, neither sex nor other variables would ordinarily produce large effect sizes in studies of leadership style. Therefore, we believe that effect sizes of the magnitude we obtained are considerably more consequential than effect sizes of the same magnitude obtained in more controlled forms of research.

Our review has not considered the extent to which the sex differences in leadership style that we have documented might produce differences in the effectiveness of leaders. Whether men or women are more effective leaders as a consequence of their differing styles is a complex question that could be addressed meta-analytically only by taking measures of group and organizational outcomes into account along with measures of leadership style. Because experts on leader effectiveness ordinarily maintain that the effectiveness of leadership styles is contingent on features of the group or organizational environment (e.g., Fiedler, 1967; Vroom \& Yetton, 1973), we are unwilling to argue that women's relatively democratic and participative style is either an advantage or disadvantage. No doubt a relatively democratic style enhances a leader's effectiveness under some circumstances, and a relatively autocratic style enhances it under other circumstances. ${ }^{22}$ Nonetheless, we note that in recent years many management and organizational consultants have criticized traditional management practices for what they believe are overly hierarchical and rigidly bureaucratic forms (Foy, 1980; Heller \& Van Til, 1986; Kanter, 1983; Naisbett, 1982; Ouchi, 1981; Peters \& Waterman, 1982). Moreover, it is consistent with many feminist theorists' descriptions of hierarchy and domination (e.g., Elshtain, 1981; Miller, 1976) to argue that employment would be less alienating if forms of interaction in the workplace were less hierarchical and instead characterized by cooperation and collaboration between collegial groups of coworkers. Indeed, both consultants and feminists have advocated organizational change toward the more democratic and participative leadership styles that our meta-analysis suggests are more prevalent among women than men.

\footnotetext{
${ }^{22}$ Consistent with the position that effectiveness of leadership styles depends on a group's task and other considerations, Wood (1987) argued, based on her meta-analysis of sex differences in group performance, that women's distinctive style of social interaction facilitated group performance at tasks requiring positive social activities such as cooperation but lacked this facilitative effect for other types of tasks.

\section{References}

Alpren, M. (1954). The development and validation of an instrument used to ascertain a school principal's pattern of behavior (Doctoral dissertation, University of Florida). Dissertation Abstracts International, 33, 1579A.

Arcy, J. A. B. (1980). Self-perceptions of leader behavior of male and female elementary school principals in selected school districts in the midwest United States (Doctoral dissertation, Iowa State University, 1979). Dissertation Abstracts International, 40, 3638A.

Ashmore, R. D., Del Boca, F. K., \& Wohlers, A. J. (1986). Gender stereotypes. In R. D. Ashmore \& F. K. Del Boca (Eds.), The social psychology of female-male relations: A critical analysis of central concepts (pp. 69-119). Orlando, FL: Academic Press.
} 
Bales, R. F. (1950). Interaction process analysis: A method for the study of small groups. Reading, MA: Addison-Wesley.

Barone, F. J. (1982). A comparative study of Theory X-Theory Y attitudes among managers and $O D$ agents. Dissertation Abstracts International, 42, 4260A. (University Microfilms No. 82-07, 156)

Bartol, K. M., \& Martin, D. C. (1986). Women and men in task groups. In R. D. Ashmore \& F. K. Del Boca (Eds.), The social psychology of female-male relations: A critical analyses of central concepts (pp. 259310). Orlando, FL: Academic Press.

Bass, B. M. (1981). Stogdill's handbook of leadership: A survey of theory and research (rev. ed.). New York: Free Press.

Baugher, S. L. (1983). Sex-typed characteristics and leadership dimensions of vocational education administrators in a midwest region of the United States (Doctoral dissertation, University of MissouriColumbia, 1982). Dissertation Abstracts International, 44, 22A.

Bayes, M., \& Newton, P. M. (1978). Women in authority: A sociopsychological analysis. Journal of Applied Behavioral Science, 14, 7-20.

Birdsall, P. (1980). A comparative analysis of male and female managerial communication style in two organizations. Journal of Vocational Behavior, 16, 183-196.

Blake, R. R., \& Mouton, J. S. (1964). The managerial grid. Houston, TX: Gulf.

Blake, R. R., \& Mouton, J. S. (1978). The new managerial grid. Houston, TX: Gulf.

Brown, S. M. (1979). Male versus female leaders: A comparison of empirical studies. Sex Roles, 5, 595-611.

Butterfield, D. A., \& Powell, G. N. (1981). Effect of group performance, leader sex, and rater sex on ratings of leader behavior. Organizational Behavior and Human Performance, 28, 129-141.

Carli, L. L. (1989). Gender differences in interaction style and influence. Journal of Personality and Social Psychology, 56, 565-576.

Coleman, D. G. (1979). Barnard's effectiveness and efficiency applied to a leader style model. Unpublished manuscript, Northeast Missouri State University, Kirksville, MO.

Crocker, J., \& McGraw, K. M. (1984). What's good for the goose is not good for the gander: Solo status as an obstacle to occupational achievement for males and females. American Behavioral Scientist, 27. 357-369.

Crudge, J. (1983). The effect of leadership styles on the rehabilitation training of student-workers (Doctoral dissertation, United States International University, 1982). Dissertation Abstracts International, 43, 3300A.

Dobbins, G. H. (1986). Equity vs equality: Sex differences in leadership. Sex Roles, 15, 513-525.

Dobbins, G. H., Pence, E. C., Orban, J. A., \& Sgro, J. A. (1983). The effects of sex of the leader and sex of the subordinate on the use of organizational control policy. Organizational Behavior and Human Performance, 32, 325-343.

Dobbins, G. H., \& Platz, S. J. (1986). Sex differences in leadership: How real are they? Academy of Management Review: 11, 118-127.

Eagly, A. H. (1987). Sex differences in social behavior: A social-role interpretation. Hillsdale, NJ: Erlbaum.

Eagly, A. H., \& Carli, L. L. (1981). Sex of researchers and sex-typed communications as determinants of sex differences in influenceability: A meta-analysis of social influence studies. Psychological Bulletin, 90, 1-20.

Eagly, A. H., Makhijani, M. G., \& Klonsky, B. G. (1990). Gender and the evaluation of leaders: A meta-analysis. Manuscript submitted for publication.

Eagly, A. H., \& Steffen, V. J. (1984). Gender stereotypes stem from the distribution of women and men into social roles. Journal of Personality and Social Psychology, 46, 735-754.

Eagly, A. H., \& Wood, W. (in press). Explaining sex differences in social behavior: A meta-analytic perspective. Personality and Social Psychology Bulletin.
Elshtain, J. (1981). Public man, private woman: Women in social and political thought. Princeton, NJ: Princeton University Press.

Feldman, D. C. (1976). A contingency theory of socialization. Administrative Science Quarterly, 2I, 433-452.

Fiedler, F. E. (1967). A theory of leadership effectiveness. New York: McGraw-Hill.

Fleishman, E. A. (1953). The management of leadership attitudes in industry. Journal of Applied Psychology, 36, 153-158.

Fleishman, E. A. (1957). The Leadership Opinion Questionnaire. In R. M. Stogdill \& A. E. Coons (Eds.), Leader behavior: Its description and measurement (pp. 120-133). Columbus, $\mathrm{OH}$ : Bureau of Business Research, Ohio State University.

Fleishman, E. A. (1960). Manual for the Leadership Opinion Questionnaire. Chicago: Science Research Associates.

Fleishman, E. A. (1970). Manual for the Supervisory Behavior Description Questionnaire. Washington, DC: American Institutes for Research.

Foy, N. (1980). The yin and yang of organizations. New York: Morrow. Ghiselli, E. E. (1964). Theory of psychological measurement. New York: McGraw-Hill.

Glass, G. V., McGaw, B., \& Smith, M. L. (1981). Meta-analysis in social research. Beverly Hills, CA: Sage.

Graen, G. (1976). Role-making processes within complex organizations. In M. D. Dunnette (Ed.), Handbook of industrial and organizational psychology (pp. 1201-1245). Chicago: Rand McNally.

Grobman, H., \& Hincs, V. A. (1956). What makes a good principal? National Association of Secondary School Principals Bulletin, 40 , 5-16.

Gupta, N., Jenkins, G. D., Jr., \& Beehr, T. A. (1983). Employee gender, gender similarity, and supervisor-subordinate cross-evaluations. Psychology of Women Quarterly, 8, 174-184.

Gustafson, L. C. (1982). The leadership role of the public elementary school media librarian as perceived by the principal and its relationship to the factors of the sex, educational background, and the work experience of the media librarian (Doctoral dissertation, University of Maryland). Dissertation Abstracts International, 43, 2206A.

Gutek, B. A., \& Morasch, B. (1982). Sex-ratios, sex-role spillover, and sexual harassment of women at work. Journal of Social Issues, 38 , 55-74.

Hall, A. H. (1983). The influence of a personal planning workshop on attitudes toward managerial style (Doctoral dissertation, University of Maryland, 1983). Dissertation Abstracts International, 44, 2953A.

Hall, J. A. (1984). Nonverbal sex differences: Communication accuracy and expressive style. Baltimore, MD: Johns Hopkins University Press.

Halpin, A. W. (1957). Manual for the Leader Behavior Description Questionnaire. Columbus, $\mathrm{OH}$ : Bureau of Business Research, Ohio State University.

Halpin, A. W. (1966). Theory and research in administration. New York: Macmillan.

Halpin, A. W., \& Winer, B. J. (1957). A factorial study of the leader behavior descriptions. In R. M. Stogdill \& A. E. Coons (Eds.), Leader behavior: Its description and measurement (pp. 39-51). Columbus, OH: Bureau of Business Research, Ohio State University.

Hedges, L. V. (1981). Distribution theory for Glass's estimator of effect size and related estimators. Journal of Educational Statistics, 6, 107128.

Hedges, L. V. (1982a). Fitting categorical models to effect sizes from a series of experiments. Journal of Educational Statistics, 7, 119-137.

Hedges, L. V. (1982b). Fitting continuous models to effect size data. Journal of Educational Statistics, 7, 245-270.

Hedges, L. V. (1987). How hard is hard science, how soft is soft science? The empirical cumulativeness of research. American Psychologist, 42, 443-455. 
Hedges, L. V., \& Becker, B. J. (1986). Statistical methods in the metaanalysis of research on gender differences. In J. S. Hyde \& M. C. Linn (Eds.), The psychology of gender: Advances through meta-analysis (pp. 14-50). Baltimore, MD: Johns Hopkins University Press.

Hedges, L. V., \& Olkin, I. (1985). Statistical methods for meta-analysis. Orlando, FL: Academic Press.

Heft, M., \& Deni, R. (1984). Altering preferences for leadership style of men and women undergraduate residence advisors through leadership training. Psychological Reports, 54, 463-466.

Heller, T., \& Van Til, J. (1986). Leadership and followership: Some summary propositions. In T. Heller, J. Van Til, \& L. A. Zurcher (Eds.), Contemporary studies in applied behavioral science: Vol. 4. Leaders and followers: Challenges for the future (pp. 251-263). Greenwich, CT: JAI Press.

Hemphill, J. K., \& Coons, A. E. (1957). Development of the Leader Behavior Description Questionnaire. In R. M. Stogdill \& A. E. Coons (Eds.), Leader behavior: Its description and measurement (pp. 6-38). Columbus, OH: Bureau of Business Research, Ohio State University.

Hennig, M., \& Jardin, A. (1977). The managerial woman. New York: Anchor Press.

Hersey, P., \& Blanchard, K. H. (1977). Manugement of organizational behavior: Utilizing human resources (3rd ed). Englewood Cliffs, NJ: Prentice-Hall.

Hersey, P., \& Blanchard, K. H. (1982). Management of organizational behavior: Utilizing human resources (4th ed.). Englewood Cliffs, $\mathrm{NJ}$ Prentice-Hall.

Hollander, E. P. (1985). Leadership and power. In G. Lindzey \& E Aronson (Eds), Handbook of social psychology (3rd ed., Vol. 2, pp. 485-537). New York: Random House.

Hughes, H., Jr., Copeland, D. R., Ford, L. H., \& Heidt, E. A. (1983) Leadership and management education and training (LMET) course requirements for recruit company and " $A$ " school instructors (Tech. Rep. No. 154, Report No. AD-A1 37306). Orlando, FL: Department of the Navy.

Hurst, A. G., Stein, K. B., Korchin, S. J., \& Soskin, W. F. (1978). Leadership style determinants of cohesiveness in adolescent groups. International Journal of Group Psychotherapy, 28, 263-277.

Jacoby, J., \& Terborg, J. R. (1975). Managerial Philosophies Scale Conroe, TX: Tcleometrics International.

Kanter, R. M. (1977a). Men and women of the corporation. New York: Basic Books.

Kanter, R. M. (1977b). Some effects of proportions on group life: Skewed sex ratios and responses to token women. American Journal of Sociology: 82, 965-990.

Kanter, R. M. (1983). The change masters: Innovations for productivity in the American corporation. New York: Simon and Schuster.

Koberg. C. S. (1985). Sex and situational influences on the use of power: A follow-up study. Sex Roles, 13, 625-639.

Kruse, L., \& Wintermantel, M. (1986). Leadership Ms.-qualified: 1. The gender bias in everyday and scientific thinking. In C. F. Graumann \& S. Moscovici (Eds.), Changing conceptions of leadership (pp. 171-197). New York: Springer-Verlag.

Lanning, G. E., Jr. (1982). A study of relationships and differences bctween management styles and staff morale as perceived by personnel in the colleges of the Ventura County community district. Dissertation Abstracts International, 43, 996A. (University Microfilms No. 82-20, 739)

Lee, D. M., \& Alvares, K. M. (1977). Effects of sex on descriptions and evaluations of supervisory behavior in a simulated industrial setting. Journal of Applied Psychology, 62, 405-410.

Lewin, K., \& Lippitt, R. (1938). An experimental approach to the study of autocracy and democracy: A preliminary note. Sociometry: 1. 292-300.
Likert, R. (1961). New patterns of management. New York: McGrawHill.

Loden, M. (1985). Feminine leadership or how to succeed in business without being one of the boys. New York: Times Books.

Maccoby, E. E. (1988). Gender as a social category. Developmental Psychology: 24, 755-765.

Marnani, E. B. (1982). Comparison of preferred leadership styles, potential leadership effectiveness, and managerial attitudes among black and white, female and male management students (Doctoral dissertation, United States International University, 1981). Dissertation Abstracts International, 43, $1271 \mathrm{~A}$.

Martinez, M. R. (1982). A comparative study on the relationship of self-perceptions of leadership styles between Chicano and Anglo teachers (Doctoral dissertation, Bowling Green State University). Dissertation Abstracts International, 43, 766A.

McGregor, D. (1960). The human side of enterprise. New York: McGraw-Hill.

McNemar, Q. (1962). Psychological statistics (3rd ed.). New York: Wiley

Miller, J. B. (1976). Toward a new psychology of women. Boston: Beacon Press.

Money, J., \& Ehrhardt, A. A. (1972). Man \& woman, boy \& girl. Baltimore, MD: Johns Hopkins University Press.

Moore, S. F., Shaffer, L., Goodsell, D. A., \& Baringoldz, G. (1983). Gender or situationally determined spoken language differences? The case of the leadership situation. International Journal of Womens Studies, 6, 44-53.

Myers, M. S. (1970). Every employee a manager. New York: McGrawHill.

Naisbitt, J. (1982). Megatrends: Ten new directions transforming our lives. New York: Warner Books.

Nicva, V. F., \& Gutek, B. A. (1981). Women and work: A psychological perspective. New York: Praeger.

O'Leary, V. E. (1974). Some attitudinal barriers to occupational aspirations in women. Psychological Bulletin, 81, 809-826.

Ott, E. M. (1989). Effects of the male-female ratio at work: Policewomen and male nurses. Psychology of Women Quarterl, 13, 41-57.

Ouchi, W. G. (1981). Theory Z: How American business can meet the Japanese challenge. Reading, MA: Addison-Wesley.

Peters, T. J., \& Waterman, R. H., Jr. (1982). In search of excellence: Lessons from America's best-run companies. New York: Harper \& Row.

Powell, G. N. (1988). Women \& men in management. Newbury Park, CA: Sage.

Reddin, W. J., \& Reddin, M. K. (1979). Educational Administrative Style Diagnosis Test (EASDT). Fredericton, New Brunswick, Canada: Organizational 'Tests.

Renwick, P. A. (1977). The effects of sex differences on the perception and management of superior-subordinate conflict: An exploratory study. Organizational Behavior and Human Performance, 19, 403415.

Rice, R. W. (1978). Construct validity of the Least Preferred Co-Worker score. Psychological Bulletin, 85, 1199-1237.

Rice, R. W., Instone, D., \& Adams, J. (1984). Leader sex, leader success, and leadership process: Two field studies. Journal of Applied Psychology, 69, 12-31.

Riger, S., \& Galligan, P. (1980). Women in management: An exploration of competing paradigms. American Psychologist, 35, 902-910.

Rosenthal, R., Hall, J. A., DiMatteo, M. R., Rogers, P. L, \& Archer, D. (1979). Sensitivity to nonverbal communication: The PONS test. Baltimore, MD: Johns Hopkins University Press.

Rosenthal, R., \& Rubin, D. B. (1986). Meta-analytic procedures for combining studies with multiple effect sizes. Psychological Bulletin. 99, 400-406. 
Russell, J. E. A., Rush, M. C., \& Herd, A. M. (1988). An exploration of women's expectations of effective male and female leadership. Sex Roles, 18, 279-287.

Sargent, A. G. (1981). The androgynous manager. New York: Amacom.

Sargent, J. F., \& Miller, G. R. (1971). Some differences in certain communication behaviors of autocratic and democratic group leaders. Journal of Communitation, 21, 233-252.

Shakeshaft, C. (1987). Women in educational administration. Newbury Park, CA: Sage.

Sirianni-Brantley, K. (1985). The effect of sex role orientation and training on leadership style (Doctoral dissertation, University of Florida, 1984). Dissertation Abstracts International, 45, 3106B.

Stake, J. E. (1981). Promoting leadership behaviors in low performance-self-esteem women in task-oriented mixed-sex dyads. Journal of Personality, 49, 401-414.

Stogdill, R. M. (1963). Mantal for the Leader Behavior Description Questionnaire-Form XII. Columbus, OH: Bureau of Business Research, Ohio State University.

Stogdill, R. M., Goode, O. S., \& Day, D. R. (1962). New leader behavior description subscales. Journal of Psychology, 54. 259-269.
Tanner, J. R. (1982). Effects of leadership, climate and demographic factors on school effectiveness: An action research project in leadership development (Doctoral dissertation, Case Western Reserve University, 1981). Dissertation Abstracts International, 43, 333A.

Taylor, S. E., Fiske, S. T., Etcoff, N., \& Ruderman, A. (1978). The categorical and contextual bases of person memory and stereotyping. Journal of Personality and Social Psychology, 36, 778-793.

Terborg, J. R. (1977). Women in management: A research review. Journal of Applied Psychology, 62, 647-664.

Van Aken, E. W. (1954). An analysis of the methods of operation of principals to determine working patterns (Doctoral dissertation, University of Florida). Dissertation Abstracts International, 14, 1983.

Vroom, V.H., \& Yetton, P. W. (1973). Leadership and decision-making. Pittsburgh, PA: University of Pittshurgh Press.

Wanous, J. P. (1977). Organizational entry: Newcomers moving from outside to inside. Psychological Bulletin, 84, 601-618.

Wood, W (1987). Meta-analytic review of sex differences in group performance. Psychological Bulletin, 102, 53-71.

Yoder, J. D. \& Sinnett, L. M. (1985). Is it all in the numbers? A case study of tokenism. Psychology of Women Quarterly, 9, 413-418.

\section{Appendix}

\section{Studies Used in the Meta-Analysis}

Adamitis, J. A. (1982). Self-perceived leadership styles of baccalaureate crime-study administrators in the United States (Doctoral dissertation, Miami University, 1981). Dissertation Abstracts International, $42,3815 \mathrm{~A}$.

Adams, E. F. (1978). A multivariate study of subordinate perceptions of and attitudes toward minority and majority managers. Journal of Applied Psychology, 63, 277-288.

Adams, J., \& Hicks, J, M. (1980). Leader sex, leader descriptions of own behavior, and subordinates description of leader behavior (Project Athena: West Point). International Journal of Women's Studies, 3, $321-326$.

Andwood, D. (1984). A comparison of perceptions and expectations for a central administrative leadership role of library media director as an indicator of his/her role behavior (Doctoral dissertation, St. John's University, 1983). Dissertation Abstracts International, 45, 693A.

Arkoff, A., \& Shears, L. M. (1961). Conceptions of "ideal" leadership in accepted and rejected principal training candidates. Journal of Educational Research, 55, 71-74.

Arnett, M. D. Higgins, R. B., \& Priem, A. P. (1980). Sex and Least Preferred Co-Worker score effects in leadership behavior. Sex Roles, 6, 139-152.

Arons, E. L. (1980). Male and female administrative potential-is there a difference? National Association of Secondary School Principals Bulletin, 64, 5-8.

Baber, C.R.(1985). Organizational perspective and selected characteristics of publicschool principals (Doctoral dissertation, Purdue University, 1984). Dissertation Abstracts international, 45, 1927A.

Baird, J. E., Jr., \& Bradley, P. H. (1979). Styles of management and communication: A comparative study of men and women. Communication Monographs, 46, 101-111.

Barbieri, E. A. (1984). Trait patterns for effective marketing performance (Doctoral dissertation, Claremont Graduate School, 1983). Dissertation Abstracts International. 44, 3790A.

Barone, F. J. (1982). A comparative study of Theory X-Theory Y attitudes among managers and $O D$ agents. Dissertation Abstracts International, 42, 4260A. (University Microfilms No. 82-07, 156)
Bartol, K. M. (1973). Male and female leaders in small work groups. East Lansing, MI: MSU Business Studies.

Bartol, K. M., \& Wortman, M. S., Jr. (1975). Male versus female leaders: Effects on perceived leader behavior and satisfaction in a hospital. Personnel Psychology, 28, 533-547.

Bartol, K. M., \& Wortman, M. S., Jr. (1976). Sex effects in leader behavior self-descriptions and job satisfaction. Journal of Psychology, 94, 177-183.

Bass, W. D. (1985). A comparison of leader behavior of elementary principals in the municipal separate, county, and consolidated school districts in Mississippi (Doctoral dissertation, University of Southern Mississippi, 1984). Dissertation Abstracts International, $46,1449 \mathrm{~A}$.

Baugher, S. L. (1983). Sex-typed characteristics and leadership dimensions of vocational education administrators in a midwest region of the United States (Doctoral dissertation, University of MissouriColumbia, 1982). Dissertation Abstracts International, 44, 22A.

Begin, F. C. (1981). An analysis of the leadership style and motivational concerns of experienced government managers (Doctoral dissertation, University of lowa). Dissertation Abstracts International, 42, $1862 \mathrm{~A}$.

Birdsall, P. (1980). A comparative analysis of male and female managerial communication style in two organizations. Journal of Vocational Behavior, 16, 183-196.

Boonon, S. (1980). Leadership styles as related to self-concept of public school principals (Doctoral dissertation, University of Alabama, 1979). Dissertation Abstracts International, 40, 4480-4481A.

Bredo, A. E. (1983). Principal-teacher infuence relations in elementary schools. Dissertation Abstracts International, 44, 332A. (University Microfilms No. 83-14, 438)

Brenner, O. C., Bromer, J. A. (1981). Sex stereotypes and leaders' behavior as measured by the agreement scale for leadership behavior. Psychological Reports, 48, 960-962.

Brown, E. D., Jr. (1986). A study of the leadership styles of principals in the exemplary secondary schools of the United States (Doctoral dissertation, University of A labama, 1985). Dissertation Abstracts inter. national, 47, 722A. 
Buckenmaier, C. S. (1982). Relationships among leadership dimensions and field dependence/independence of elementary school administrators (Doctoral dissertation, Vanderbilt University, 1981). Dissertation Abstracts International, 42, 4983A.

Buckiewicz, D. R. (1975). An analysis of leader behavior in the physical education departments of the community colleges of California, Oregon and Washington (Doctoral dissertation, University of Oregon, 1974). Dissertation Abstracts International, 35, 5087A.

Butters, M. A., \& Gade, E. M. (1982). Job satisfaction and leadership behavior of residence hall assistants. Journal of College Student Personnel, 23, 320-324.

Cain, R. A. (1980). Collective negotiation attitudes and principal leadership style (Doctoral dissertation, United States International University, 1979). Dissertation Abstracts International, 41, 862A.

Camden, C.. \& Witt, J. (1983). Manager communicative style and productivity: A study of female and male managers. International Journal of Women's Studies, 6, 258-269.

Carpeno, L. (1976). Expectations of male/female leadership styles in an educational setting. Dissertation Abstracts International, 37 , 1482B. (University Microfilms No. 76-21, 223)

Chapman, J. B. (1974). A comparative analysis of male and female leadership styles in similar work environments (Doctoral dissertation, University of Nebraska). Dissertation Abstracts International, $35,2456 \mathrm{~A}$.

Charters, W. W, Jr, \& Jovick, T. D. (1981). The gender of principals and principal-teacher relations in elementary schools. In P. A. Schmuck, W. W. Charters, Jr., \& R. O. Carlson (Eds.), Educational policy and management: Sex differentials (pp. 307-331). New York: Academic Press.

Christensen, C. E., Milner, K., \& Christensen, J. E. (1978). An analysis of faculty perceptions of leadership qualities of male and female physical education departments. Research Quarterly, 49, 269-277.

Cimperman, R. M. (1986). A comparison of perceived primary leadership style, style range, and leadership style adaptability of female and male administrators in the Wisconsin vocational, technical and adult education system. Dissertation Abstracts International, 46, 2141A. (University Microfilms No. 85-24, 461)

Cole, K. W. (1977). The perceptions of leader behavior of male and female administrators in the Archdiocese of Washington, D. C, secondary schools (Doctoral dissertation, Catholic University of America). Dissertation Abstracts International, 38, 1769A.

Cormell, M. S. (1979). Leadership styles of effective school principals. Unpublished doctoral dissertation, United States International University.

Dansby, M. R. (1979). Leader effectiveness as a function of leader's sex and leadership style (Doctoral dissertation, University of Florida). Dissertation Abstracts International, 40, 1951B.

Davenport, I. W. (1977). Analysis of the perceived leader behavior of male and female elementary school principals (Doctoral dissertation, University of Missouri-Columbia, 1976). Dissertation Abstracts International, 37, 5476A.

Davis, M., \& Songer-Nocks, E. (1978, March). Comparing leader-group relations in male and female groups. Paper presented at the meeting of the Southeastern Psychological Association, Atlanta, GA.

Day, D. R., \& Stogdill, R. M. (1972). Leader behavior of male and female supervisors: A comparative study. Personnel Psychology, 25. $353-360$.

Denmark, F. L., \& Diggory, J. C. (1966). Sex differences in attitudes toward leaders' display of authoritarian behavior. Psychological Reports, 18, 863-872.

De Rosa, C. A. (1981). A study of the relationship between selected variables and a teacher's perception of an elementary school principal's administrative behavior (Doctoral dissertation, University of Michigan). Dissertation Abstracts International, 42, 2389A.

Dollinger, L. D. (1980). Leadership styles of male and female elemen- tary principals in the states of Iowa and Missouri. Masters Abstracts International, 18, 274. (University Microfilms No. 13-14, 888)

Donnell, S. M., \& Hall, J. (1980). Men and women as managers: A significant case of no significant difference. Organizational $D y$ namics, 8, 60-77.

Douglas, L. D., \& Simonson, S. V. (1982). A comparison of life experiences and leader behaviors between male and female superintendents. Dissertation Abstracts International, 43, 602A. (University Microfilms No. 82-18, 109)

Dragon, A. C. (1977). Self-descriptions and subordinate descriptions of the leader behavior of library administrators (Doctoral dissertation, University of Minnesota, 1976). Dissertation Abstracts International, 37, 7380.

Duhon, M. D. (1986). Androgyny and LPC as factors in leadership style: A study of effectiveness and interactional processes. Dissertation Abstracts International, 47, 2209B. (University Microfilms No. 86-17, 891)

Dumas, A. P. (1981). An investigation of the relationship between leadership style and philosophical orientation of elementary and secondary school principals. Dissertation Abstracts International, 42, 1872A. (University Microfilms No. 81-23, 012)

East, E. (1981). A comparative study of male and female perceptions of leadership styles of selected elementary school principals in Florida. Dissertation Abstracts International, 42, 2391A. (University Microfilms No. 81-25, 820)

Eblen, A. (1984). Communication, gender, leadership, and commitment in the organization (Doctoral dissertation, University of Oregon, 1983). Dissertation Abstracts International. 44, $2291 \mathrm{~A}$.

Eskilson, A. (1975). Sex composition and leadership in small groups (Doctoral dissertation, University of Illinois, 1974). Dissertation Abstracts International, 35, 7027B.

Espy, A. M. (1976). The principal's leadership style and the job satisfaction of teachers in a selected urban school district (Doctoral dissertation, University of Florida, 1975). Dissertation Abstracts International, 36. 7770A.

Farber, B. E. (1969). Organizational climate of public elementary schools as related to dogmatism and selected biographical characteristics of principals and teachers, and selected school and school community characteristics (Doctoral dissertation, Wayne State University, 1968). Dissertation Abstracts International, 29, 3368A.

Feldman, J. R. (1986). Leadership emergence in adult students (Doctoral dissertation, Georgia State University, 1985). Dissertation $A b$ stracts International, 46, 2580A.

Fitzpatrick, R., \& Cole, M. E. (1977). Some characteristics of female and male managers. Pittsburgh, PA: Psychological Service of Pittsburgh.

Francke, C. A. (1975). Perceived performance differences between women and men supervisors and implications for training (Doctoral dissertation, Michigan State University). Dissertation Abstracts International, 36, 1349A.

Friedman, M. J. (1981). Differences in assessment center performance as a function of the race and sex of ratees and the race of assessors (Doctoral dissertation, University of Tennessee at Knoxville, 1980). Dissertation Abstracts International, 41, 3924B.

Gaudreau, P. A. (1975). Investigation of sex differences across job levels. Dissertation Abstracts International, 36, 1957B. (University Microfilms No. 75-22, 019)

Gilligan, T. P. (1982). An analysis of the leader style of elementary public school principals as perceived by their faculty (Doctoral dissertation, George Washington University). Dissertation Abstracts International, 43, 604A.

Gorman, H. T. (1980). The relationship between gender, sex-role description, attitudes toward women, and the perceived leadership behavior of male and female elementary school principals. Disserta- 
tion Abstracts International, 41, 476A. (University Microfilms No. $80-17,538$ )

Grimes, E. S. (1983). Leadership styles of female and male elementary principals (Doctoral dissertation, University of Northern Illinois, 1982). Dissertation Abstracts International, 44, 28A.

Grimsley, L. G. C. (1980). Sex effects in leader problem-solving: A bilateral model of leadership behavior. Dissertation Abstracts Internaional, 41,1090B. (University Microfilms No. 80-20,531)

Grobman, H., \& Hines, V. A. (1956). What makes a good principal? National Association of Secondary School Principals Bulletin, 40, $5-16$.

Gupta, N., Jenkins, G. D., Jr., \& Beehr, T. A. (1983). Employee gender, gender similarity, and supervisor-subordinate cross-evaluations. Psychology of Women Quarterly, 8, 174-184.

Hamilton, E. E. (1983). Androgyny and leadership: An empirical field study of effective influence in decision-making groups. Dissertation Abstracts International, 43, 2379B. (University Microfilms No. 8223,210 )

Heischmidt, K. A. (1985). Developmental task resolution as a predictor of leadership style (Doctoral dissertation, University of Southern Illinois, 1984). Disseriation Abstracts International, 46, $1562 \mathrm{~A}$.

Helmich, D. L. (1974). Male and female presidents: Some implications of leadership style. Human Resource Management, 12, 25-26.

Hemphill, J. K., Griffiths, D. E., \& Frederiksen, N. (1962). Administrative performance and personality: A study of the principal in a simulated elementary school. New York: Teachers College, Columbia University:

Jago, A. G., \& Vroom, V. H. (1982). Sex differences in the incidence and evaluation of participative leader behavior. Journal of Applied Psychology, 67, 776-783.

Jocelyn, $J$. (1985). The sex variable of participative decision making (Doctoral dissertation, University of Oregon, 1984). Dissertation Abstracts International, 46, 82A

Joerger, J. H. (1985). A field study of fear of success, internal-external locus of control and performance ratings among professional men and women (Doctoral dissertation, University of Northern Colorado, 1984). Dissertation Abstracts International, 45, $3371 \mathrm{~B}$.

Johnson, F. D. H. (1977 a). The relationship between rule administration and the leadership behavior of black mate and female urban elementary school principals (Report No. EA-010-524). Norfolk, VA: Annual National Conference on Urban Education. (ERIC Document Reproduction Service No. ED 153338 )

Johnson, F. D. H. (1977b). The relationship between rule administration, leadership behavior and the sex of elementary school principals (Doctoral dissertation, Pennsylvania State University). Dissertation Abstracts International, 38,571A.

Johnson, K. A. (1983). The perceived real and ideal leader behavior of selected male and female department heads of physical education in colleges and universities (Doctoral dissertation, University of Georgia, 1982). Dissertation Abstracts International, 43, 2274A.

Kappelman, S. K. (1981). Teachers' perceptions of principals' bases of power in relation to principals' styles of leadership. Dissertation $A B-$ stracts International, 42, 2405A. (University Microfilms No. 81-25, 884)

Keener, B. J. (1977). An analysis of the perceptions of the leadership behavior of male and female University of Florida administrators (Doctoral dissertation, University of Florida, 1976). Dissertation Abstracts International, 37, 4023A.

King, P. J. (1978), An analysis of teachers' perceptions of the leadership styles and effectiveness of male and female elementary school principals (Doctoral dissertation, University of Southern California). Dissertation Abstracts International, 39, 2658A.

King, W. C. (1981). Relationship between stress and leadership style of school managers (Doctoral dissertation, University of La Verne, 1979). Dissertation Abstracts International, 41, 4237^.
Kobayashi, K. J. (1974). A comparison of organizational climate of schools administered by female and male elementary school principals (Doctoral dissertation, University of the Pacific). Dissertation Abstracts International $35,129 \mathrm{~A}$.

Konitsney, D. A. (1982). Self-efficacy of perceived performance of leader behaviors under varied group sex compositions: Towards an understanding of sex differences in leadership. Dissertation $A b$ stracts intemational. 42, 4260A. (University Microtilms No. 82-07, 156)

Korabik, K. (1982). Sex-role orientation and leadership style. International Journal of Women's Studies, 5, 329-337.

Lampos, J. A. (1985). The role of counseling training in the leadership style of secondary school principals as perceived by themselves and their subordinates. Dissertation Abstracts International, 45, 3499A. (University Microfilms No. 85-03, 176)

Lanning, G. E., Ir. (1982). A study of relationships and differences between management styles and staff morale as perceived by personnel in the colleges of the Ventura County community district. Dissertation Abstracts International, 43, 996A. (University Microfilms No. 82-20, 739)

Latta, J. A., \& Emener, W. G. (1983). State vocational rehabilitation agency leadership behavior styles. Journal of Rehabilitation Administration. 7, 141-148,

Lemon, D. K., Hovel, I., Lindquist, J., \& Porter, A. (1982). The elementary school principalship in North Dakota (Report No. EA-01 5-599). Grand Forks, ND: Bureau of Educational Research and Services. (ERIC Document Reproduction Service No. ED 228 746)

Lewis, J. P. (1987). The relationship between supervisors' attributions for the causes of employee performance and supervisors' structuring and consideration behavior. Dissertation Abstracts International, 47. 4331B. (University Microfilms No. 87-01, 756)

Linimon, D., Barron, W. L., III, \& Jalbo, T. (1984). Gender differences in perceptions of leadership. Sex Roles, $11,1075-1089$.

Longstreth, C. A. (1973). An analysis of the perceptions of the leadership behavior of male and female secondary school principals in Florida (Doctoral dissertation, University of Miami). Dissertation Abstracts International, 34, 2224A.

Malone, P. F. (1984). Cognitive style and leader adaptability of managers (Doctoral dissertation, University of Oklahoma). Dissertation Abstracts International, 45, $1268 \AA$

Marnani, E. B. (1982). Comparison of preferred leadership styles, potential leadership effectiveness, and managerial attitudes among black and white, female and male management students (Doctoral dissertation, United States International University, 1981). Dissertation Abstracts International, 43,1271A.

McDonnell, J. F. (1974). An analysis of participative management as a choice of leadership style (Doctoral dissertation, Claremont Graduate School). Dissertation Abstracts International, 35, 1339A.

McGrath, W. M. (1982). I cadership style of selected Arizona community college administrators. Dissertation Abstracts International, 43, 1776A. (University Microfilms No. 82-24, 793)

McMahon-Dumas, C. E. (1981). An investigation of the leadership styles and effectiveness dimensions of principals, and their relationship with reading gain scores of students in the Washington, D. C., public schools. Dissertation Abstracts Intemational. 42,1881A. (University Microfilms No. 81-21, 448)

Meyer, E. J. (1983). An analysis of self-perceived leadership of Air Force communications-electronics junior grade officers employing the Leader Effectiveness and Adaptability Description (Doctoral dissertation, University of Southern Mississippi). Dissertation Abstracts International, 44, 1277A.

Millard, R. J.. \& Smith, K. H. (1985). Moderating effects of leader $5 e x$ on the relation between leadership style and perceived behavior patterns. Genetic, Social and General Psychology Monographs, 111. 305-316 
Miller, N. S. (1979). Male and female leadership style and self-perceived behavior compared (Doctoral dissertation, State University of New York at Buffalo). Dissertation Abstracts International, 40, 1794A.

Milner, E. K., King, H. A., \& Pizzini, E. L. (1979). Relationship between sex and leadership behavior of department heads in physical education. Research in Higher Education, 10, 113-121.

Mitchell, T. R. (1969). Leader complexity, leadership style and group performance (Doctoral dissertation, University of Illinois at Urbana). Dissertation Abstracts International, 30, 3375B.

Modiste, C. J. (1984). An investigation of management styles of selected black public school administrators as affected by sex, age, and geographical location. Dissertation Abstracts International, 45, 41A. (University Microfilms No. 84-07, 303)

Monie, W. D., Jr. (1981). The relationship between seventh and ninth grade teachers' leadership style preferences and administrator perceptions of their effectiveness. Dissertation Abstracts International, 42, 2413A. (University Microfilms No. 81-21, 098)

Morrison, A. M., White, R. P., \& Van Velsor, E. (1987). Breaking the glass ceiling: Can women reach the top of Americas largest corporations? Reading, MA: Addison-Wesley.

Morsink, H. M. (1970). Leader behavior of men and women principals. National Association of Secondary School Principals Bulletin. $54,80-87$.

Moye, J. W. (1980). The relationship between personal and experience variables of Dade County secondary school principals and subordinates' perceptions of leader behavior (Doctoral dissertation, Mississippi State University). Dissertation Abstracts International, 41, 1323A.

Mulkerne, S. M. (1980). A comparative study of perceived leadership behavior in male and female exceptional student education directors in the state of Florida. Dissertation Abstracts International, 41, 3988A. (University Microfilms No. 81-05, 598)

Nimry, F. F. (1986). The association of leadership style with job satisfaction in consulting businesses (Doctoral dissertation, American University). Dissertation Abstracts International, 47, 978A.

Oddou, G. R. (1984). The emergence of leaders in natural work groups: A test of self-monitoring theory (Doctoral dissertation, Brigham Young University, 1983). Dissertation Abstracts International, 44, 2284B.

Orr, W. L. (1980). An investigation of leadership styles of middle school principals in Delaware, New Jersey and Pennsylvania (Doctoral dissertation, Temple University). Dissertation Abstracts International, 41, 1878A.

Osborn, R. N., \& Vicars, W. M. (1976). Sex stereotypes: An artifact in leader behavior and subordinate satisfaction analysis? Academy of Management .ournal, 19, 439-449.

Parke, J. E. P. (1986). Comparisons of decision-making styles of Florida community and junior college department chairpersons and division directors (Doctoral dissertation, University of North Carolina at Greensboro, 1985). Dissertation Abstracts International, 46, 1802A.

Parks, D. J. (1970). A study of relationships between interpersonal relations orientations and leader behaviors of elementary principals. Dissertation Abstracts International, 31, 2657A. (University Microfilms No. 70-24, 104)

Pate, T. M., Jr. (1979). The relationship of the elementary principal's leadership style to his self-concept of his ability to communicate and his knowledge of his job (Doctoral dissertation, George Peabody College for Teachers, 1978). Dissertation Abstracts International, 39, 6445A.

Perea, R. D. (1981). The relationship of initiating structure, consideration and locus of control on leader behavior of women and men in educational leadership roles. Unpublished doctoral dissertation, University of New Mexico.
Peregrine, P. E. (1983). The robustness of managerial life in schools: A test of contingency theory. Dissertation Abstracts International, 43 , 2849A. (University Microfilms No. 83-00, 320)

Perritt, L. J. C. (1983). Job satisfaction as a function of worker and supervisor characteristics (Doctoral dissertation, University of Kentucky). Dissertation Abstracts International, 44, 2002B.

Petty, M. L. (1986). A profile of college student leaders relating personality types, learning styles, and leadership approaches (Doctoral dissertation, Florida State University, 1985). Dissertation Abstracts International, 46, 3621A.

Petty, M. M., \& Bruning, N. S. (1980). A comparison of the relationships between subordinates' perceptions of supervisory behavior and measures of subordinates' job satisfaction for male and female leaders. Academy of Management Journal, 23, 717-725.

Petty, M. M., \& Lee, G. K., Jr. (1975). Moderating effects of sex of supervisor and subordinate on relationships between supervisory behavior and subordinate satisfaction. Journal of Applied Psychology, 60, 624-628.

Powell, G. N., Butterfield, D. A., \& Mainiero, L. A. (1981). Sex-role identity and sex as predictors of leadership style. Psychological Re ports, 49. 829-830.

Pruitt, P. J. (1977). Perceived leader behavior of male and female intercollegiate athletic directors in the United States (Doctoral dissertation, University of Kentucky, 1976). Dissertation Abstracts International, 37, 6199A.

Quinn, K. I. (1977). Self-perceptions of leadership behaviors and decision-making orientations of men and women elementary school principals in Chicago public schools (Doctoral dissertation, University of Illinois at Urbana-Champaign, 1976). Dissertation Abstracts International, 37, 6199A.

Rice, R. W., Bender, L. R., \& Vitters, A. G. (1980). Leader sex, follower attitudes toward women, and leadership effectiveness: A laboratory experiment. Organizational Behavior and Human Performance, 25, $46-78$.

Richardson, D. K. (1981). A study of the leadership styles of the chief student affairs administrators in Southern Baptist colleges and universities. Dissertation Abstracts International, 41, 2963A. (University Microfilms No. 80-29, 015)

Robertson, D. R. (1981). A study of leadership style: A comparison of secular and biblical settings (Masters thesis, Oral Roberts University, 1980). Masters Abstracts International, 19, 274.

Robson, G. N. (1985). A comparison of leadership styles of male and female elementary school administrators in Prince George's County, Maryland. Dissertation Abstracts International, 46, 1152A. (University Microfilms No. 85-15, 767)

Rogers, D. R. H. (1980). A comparison of teachers' perceptions of female versus male principals' leader behavior and organizational climate in elementary schools (Doctoral dissertation, East Tennessee State University). Disseriation Abstracts International, 41,1881A.

Rogers, M. (1977). A descriptive study of leadership effectivencss of male and female elementary school principals based upon self perception and the perception of their teachers (Doctoral dissertation, United States International University). Dissertation Abstracts International, 41,1880A.

Rosenfeld, L. B., \& Fowler, G. D. (1976). Personality, sex, and leadership style. Communication Monographs, 43, 320-324.

Roussell, C. (1974). Relationship of sex of department head to department climate. Administrative Science Quarterly, 19, 211-220.

Ruch, L. O., \& Newton, R. R. (1977). Sex characteristics, task clarity, and authority. Sex Roles, 3, 479-494.

Sabermahani, M. A. (1984). The relationship between leadership styles and graduate academic majors. Dissertation Abstracts International, 45, 1262A. (University Microfilms No. 84-18, 591)

Samuelson, J. L. (1984). The relationship between gender and the interpersonal communication skills of midlevel managers in California 
community colleges (Doctoral dissertation, University of San Francisco, 1983). Dissertation Abstracts International, 45, 1008A.

Scafidel, R. J. (1983). An analysis of the relationship between teachers' perceived leadership style of the principal and the implementation of continuous progress. Dissertation Abstracts International, 43, 2850A. (University Microfilms No. 82-23, 268)

Schneier, C. E. (1978). The contingency model of leadership: An extension to emergent leadership and leader's sex. Organizational Behavior and Human Performance, 21, 220-239.

Schneier, C. E., \& Bartol, K. M. (1980). Sex effects in emergent leadership. Journal of Applied Psychology, 65, 341-345.

Shareatpanahi, M. (1982). The relationship between gender and perceived leader behavior of male and female elementary school principals (Doctoral dissertation, University of San Francisco). Dissertation Abstracts International, 43, 618A.

Sheffield, A. C. (1983). A study of the relationship between the leadership dimensions of initiating structure and consideration of school principals and their attitudes toward conflict management (Doctoral dissertation, Vanderbilt University). Dissertation Abstracts International, 44, 1656A.

Sims, A. L. (1982). Effects of sex differences on leadership styles and probable effectiveness of elementary principals: As perceived by themselves and their teachers using the Hersey-Blanchard insirument in four medium-sized California school districts (Doctoral dissertation, Brigham Young University, 1981). Dissertation $\mathrm{A} b$. stracts International, 42, 3378 A.

Sirotti, S. B. (1986). The effect of task responsibilities on assistant principals' roles (Doctoral dissertation, Western Michigan University, 1985). Dissertation Abstracts International, 47, 746A.

Smith, A. C., Jr. (1982). Correlates of first-line supervisory effectiveness (Doctoral dissertation, Virginia Polytechnic Institute and State University, 1981). Dissertation Abstracts International, 42, 4429A.

Smith, B. B. (1976). The relationship between leadership behavior and need-press measures of male and female supervisors in masculine and feminine sex-typed work settings. Dissertation Abstracts International, 36, 47 10B. (University Microfilms No. 75-29, 753)

Smith, M. D. (1983). Differences in leadership behaviors of male and female elementary school principals in West Virginia as perceived by the superintendent, the male elementary principal, and the female elementary principal (Doctoral dissertation, West Virginia University, 1982). Dissertation Abstracts International, 43, $3481 \mathrm{~A}$.

Snell, S. J. A. (1981). A tripartite comparative analysis by sex of the perceptions of public school superintendents and their school board presidents relating to selected dimensions of administrative behavior (Doctoral dissertation, Ohio University, 1980). Dissertation Abstracts International, 42, 2427A.

Snodgrass, S. E., \& Rosenthal, R. (1984). Females in charge: Effects of sex of subordinate and romantic attachment status upon self-ratings of dominance. Journal of Personality, 52, 355-371.

Spence, B. A. (1971). Sex of teachers as a factor in their perception of selected leadership characteristics of male and female elementary school principals (Doctoral dissertation, Purdue University). Dissertation Abstracts International, 32, 2985A.

Spillman, B, Spillman, R., \& Reinking, K. (1980). A dynamic analysis of the effects of sex and androgyny on leadership emergence (Report No. CS-502855). Davis, CA: University of California. (ERIC Document Reproduction Service No. ED 184 175)

Steers, R. M. (1977). Individual differences in participative decisionmaking. Human Relations, 30, 837-847.
Stemler, J. G. (1981). Fiedler's LPC scale: Behavioral and attitudinal correlates (Doctoral dissertation, University of Cincinnati, 1980). Dissertation Abstracts International, 41, 3938B.

Sunderland, J. D. (1982). A comparison of the leadership attitudes of male and female athletic directors (Doctoral dissertation, University of Oregon, 1981). Dissertation Abstracts International, 42, 3502A.

Tanner, J. R. (1982). Effects of leadership, climate and demographic factors on school effectiveness: An action research project in leadership development (Doctoral dissertation, Case Western Reserve University, 1981). Dissertation Abstracts International, 43, 333A.

Thomas, V. G., \& Littig, L. W. (1985). A typology of leadership style: Examining gender and race effects. Bulletin of the Psychonomic Society, 23, 132-134.

Van Aken, E. W. (1954). An analysis of the methods of operation of principals to determine working patterns (Doctoral dissertation, University of Florida). Dissertation Abstracts International, 14, 1983.

Van Meir, E. J., Jr. (1973). Leadership behavior of male and female elementary principals: A comparison by sex. Marquette University Education Review, 4, 8-11.

Vaughans, K. C. (1985). The efficacy of student leadership training (Doctoral dissertation, Adelphi University). Dissertation Abstracts International, 46, 2107B.

Wall, J. K. (1982). The relationship of gender and perceived sex role identity to the leadership style, range, and adaptability of selected graduate students. Disseriation Abstracts International, 43, 2046B. (University Microfilms No. 82-26, 272)

Ward, J. M., Jr. (1977). Normative determinants of leadership. Dissertation Abstracts International, 37, 47108B. (University Microfilms No. $77-5,206)$

Webb, J. G. (1981). The communication behavior of leaders in small group discussion (Doctoral dissertation, University of Michigan). Dissertation Abstracts International, 42, 456A.

Wexley, K. N., \& Hunt, P. J. (1974). Male and female leaders: Comparison of performance and behavior patterns. Psychological Reports, $35,867-872$.

Williams, L. C. (1982). Relationship of sex of coach, level of school, and type of sport on measures of actual and ideal leadership behavior (Doctoral dissertation, University of Southern California). Dissertation Abstracts International, 43, 109A.

Winther, D. A., \& Green, S. B. (1987). Another look at gender-related differences in leadership behavior. Sex Roles, 16, 41-56.

Wood, J. T. (1981). Sex differences in group communication: Directions for research in speech communications and sociometry. Journal of Group Psychotherapy, Psychodrama and Sociometry, 34, 2431.

Yoder, J. D., Adams, J., \& Hicks, J. M. (1986). When sex-roles and work roles conflict: A critical look at standards of evaluation. Unpublished manuscript, Webster University.

Young, E. M. W. (1981). A study of the self-perception and subordinate perception of the leadership bchavior of black library directors (Doctoral dissertation, Vanderbilt University, 1980). Dissertation Abstracts International, 42, 499A.

Young, J. C. (1981). Comparisons of leader style, behaviors and effectiveness of male and female coaches (Report No. SP-022744). College Park, MD: University of Maryland. (ERIC. Document Reproduction No. ED 231 830)

Received November 14, 1988

Revision received October 25, 1989 Accepted November 16,1989 